\title{
المخاطر الأخلاقية والأزمة العالمية المعاصرة \\ وجهة نظر إسلامية
}

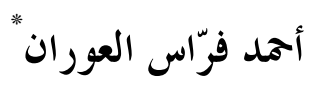

الملخص

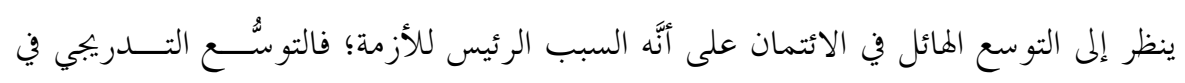

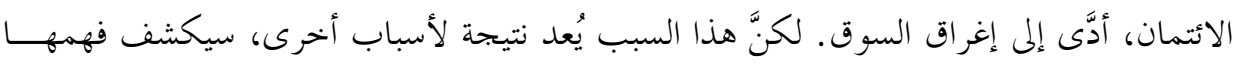

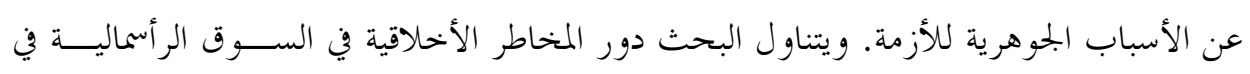

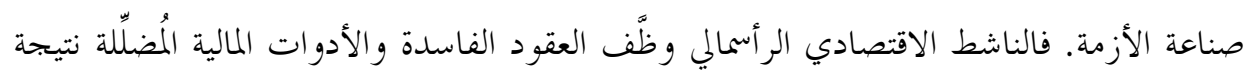

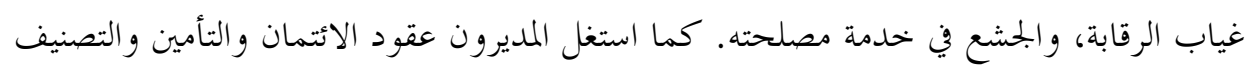

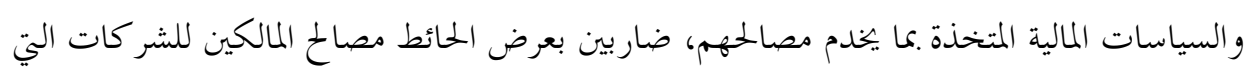
يديروها والمو اطنين، بل والاقتصاد كله.

وتخلص الدراسة إلى أنَّ الأسباب الجوهرية الكامنة وراء الأزمة، تكمن في السلوك الرأسمالي،

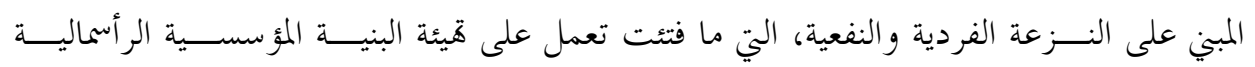

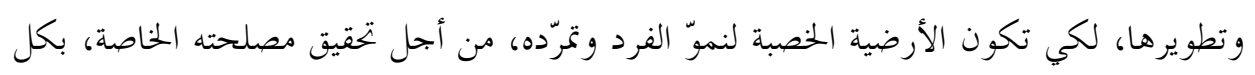
الوسائل المتاحة.

الكلمات المفتاحية: أسباب الأزمة، المخحاطر الأخلاقية، عقود الائتمان، السلوك الرأســـالي، التزعة النفعية، غياب الرقابة، الإنسان الاقتصادي.

\section{Abstract}

This study discusses moral hazard's role in the making of the crisis. Absence of regulation led capitalist economic agents to employ rotten contracts, doubtful instruments, greed and hideous intentions to their interests. Numerous managers (ab) used credit lending, insurance, and rating contracts and monetary policy to their benefit and to the detriment of those of companies, stockholders, and the entire economy.

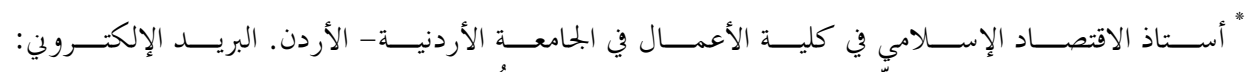
sroran@ju.edu.jo 
The study concludes that the root causes lie in the capitalist's behavior, built upon individualism and utilitarianism. These were employed to prepare the needed structure, and fertile ground, for individuals to grow, develop, and rebel, in the pursuit of self- interest by all means.

Keywords: Crisis causes, Moral hazard, individualism, utilitarianism, Insurance contracts, Homo oeconomicus.

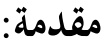

على الرغم من أنَّ اهيار جدار برلين عام 1919 لا يعدو كونه -من وجهة نظـــ

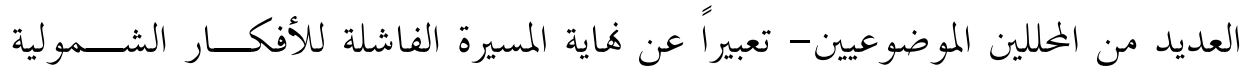

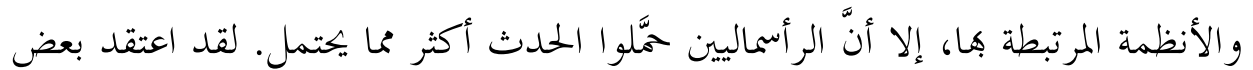

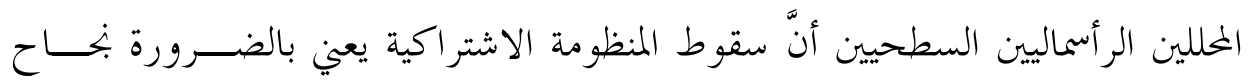

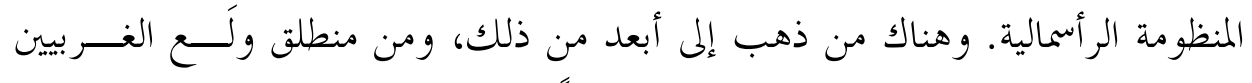

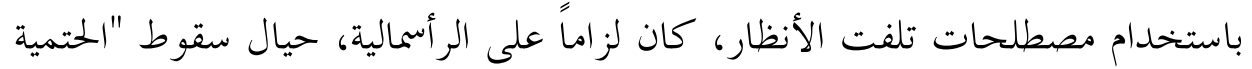

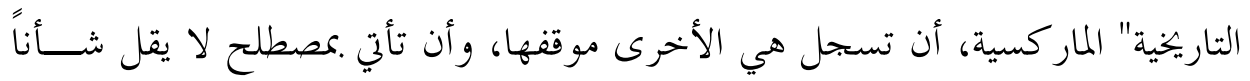

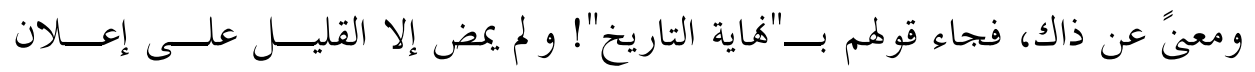

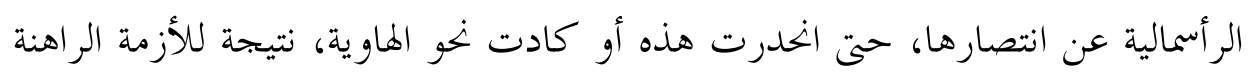

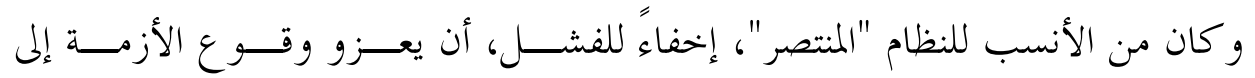

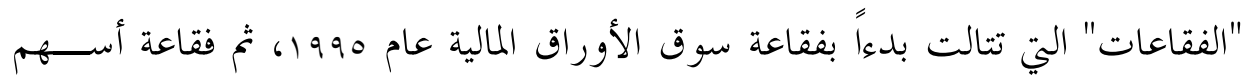

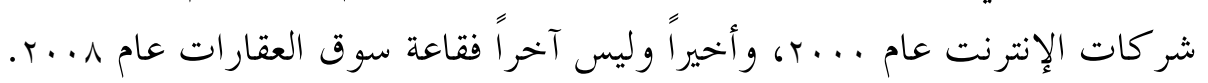
ومع أنّه قيل الكثير عن الأزمة المالية/ الاقتصادية المعاصرة (لاحقاً الأزمة)، فإنَّ ثمّة

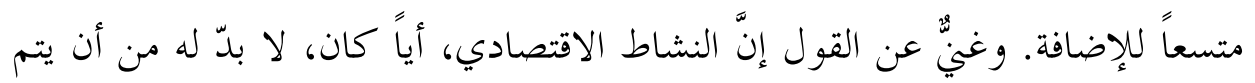

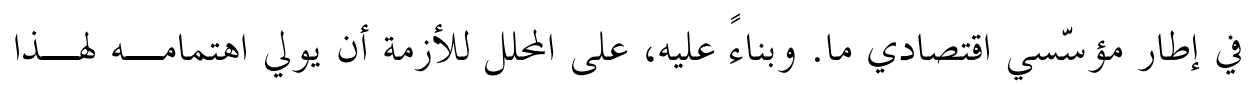
الجلانب وما يتّصل به، لكي يتمكن من الوقوف على الأسباب، دون الأعــــراض الــتي

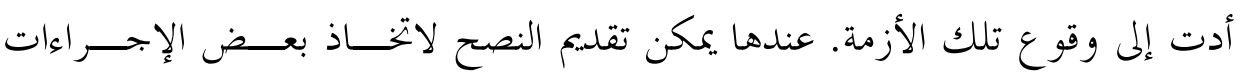


لإصلاح الوضع القائم، على المدى القصير، والحيلولة دون الوقوع في أزمة مماثلــة، إذا كان ذلك ممكناً، على المدى الطويل.

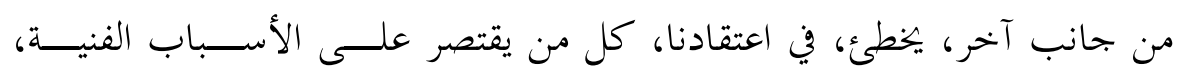

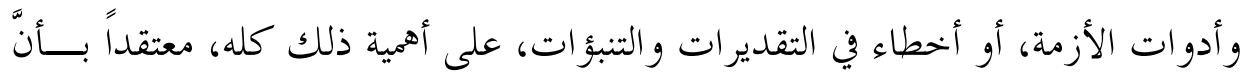

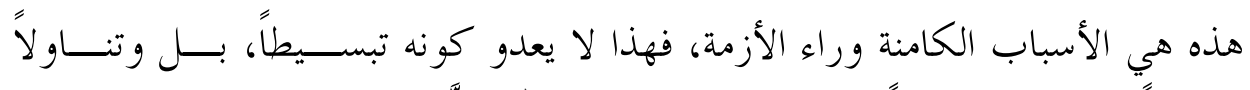

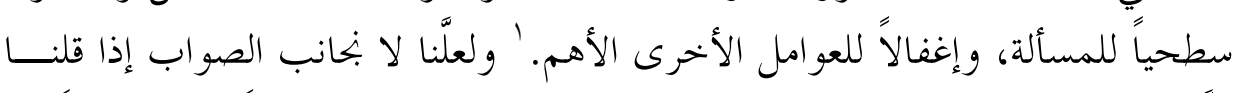

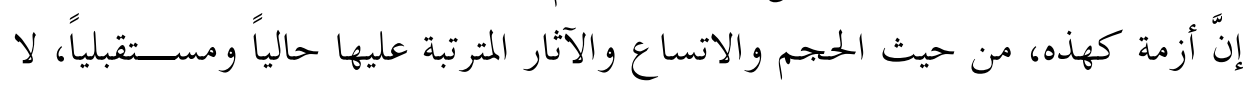

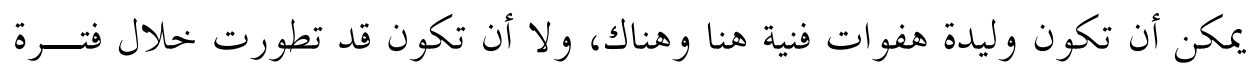

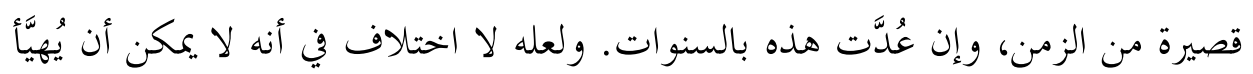

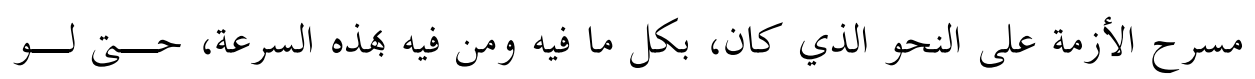
افترضنا تكاتف الجهود لإعداد ذلك.

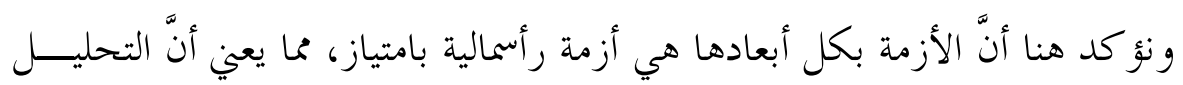

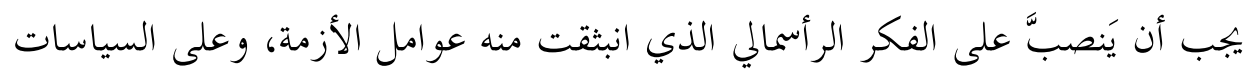

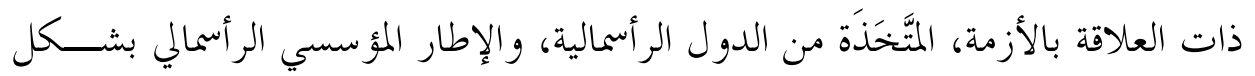

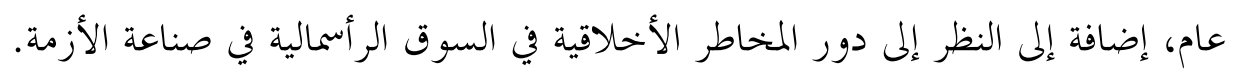
وسيتم تناول هذه الأزمة من منظور اقتصادي إسلامي. وهذا يعــني أنَّ التحليـلـل

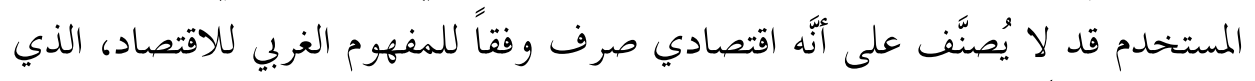

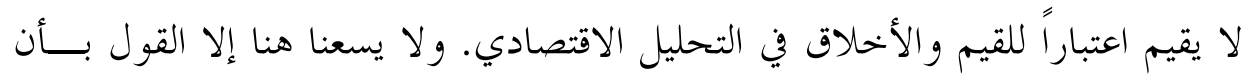

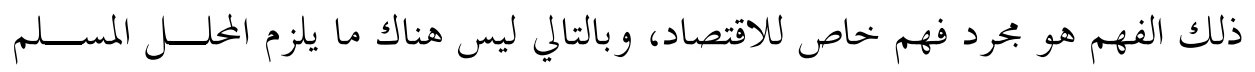

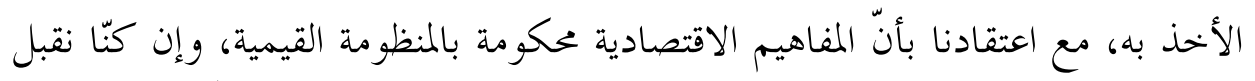

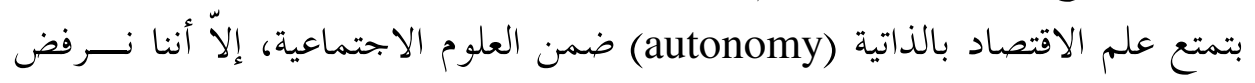

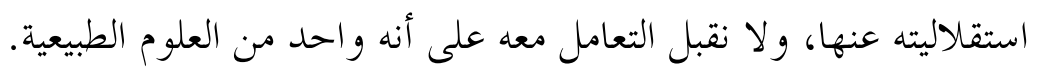

${ }^{1}$ Oran, Ahmad. The Future of the Capitalist's Market Economic Theory, A Paper presented at the international conference on "Economic Theory and Social Market Theory", sponsored by Al-Quds Venter and Konrad-Adenauer-Stiftung, Amman, July, 25 ${ }^{\text {th }}, 2009$. 


\section{أولاً: الأزمة المالية ومفهوم السّوق}

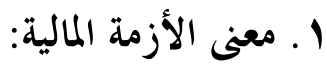

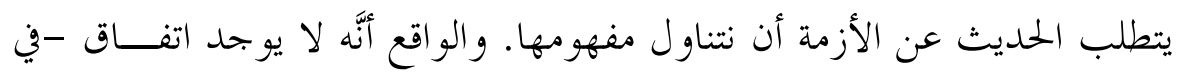

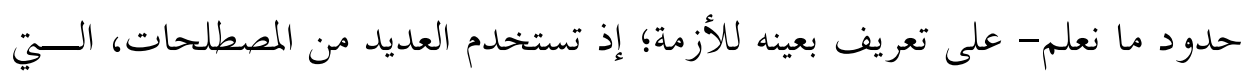

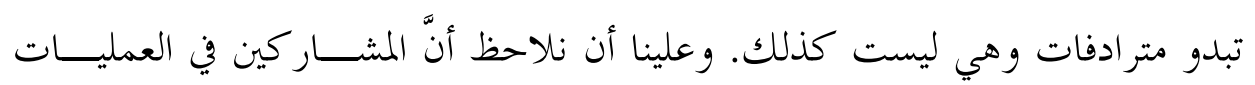

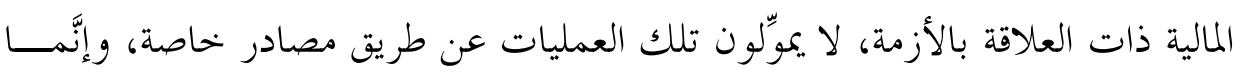

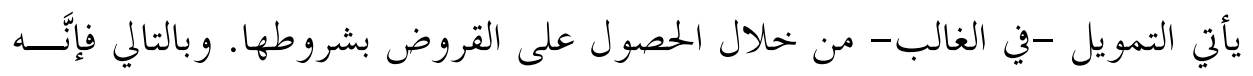

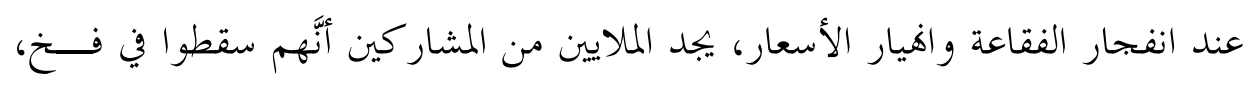

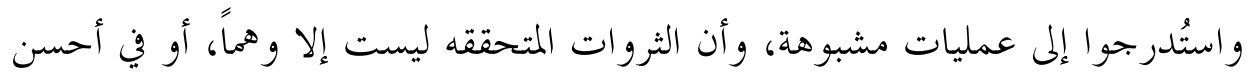

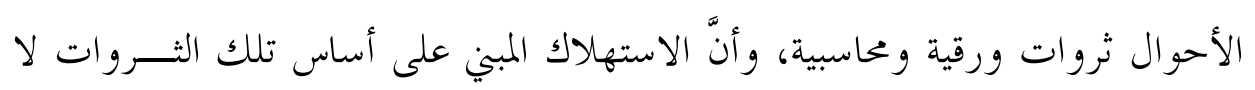

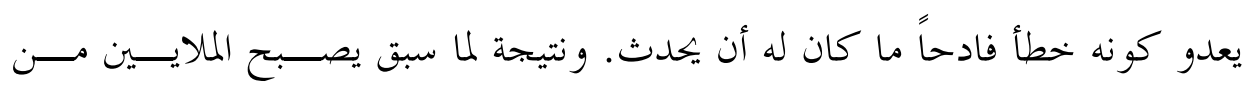

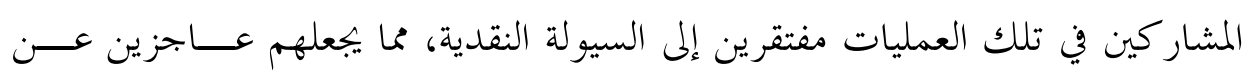

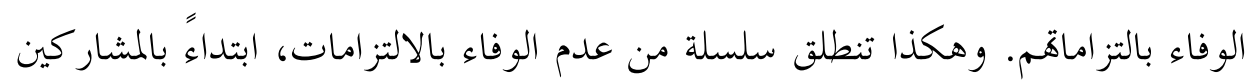

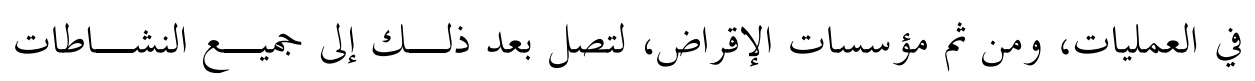

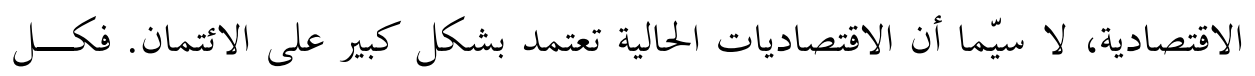

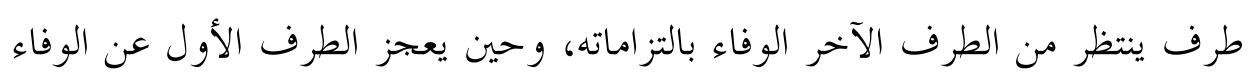

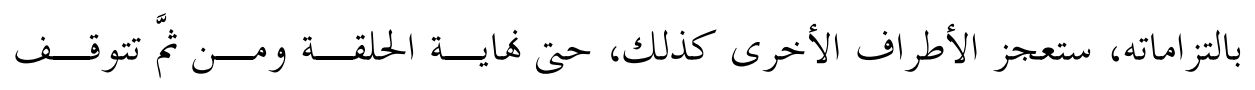

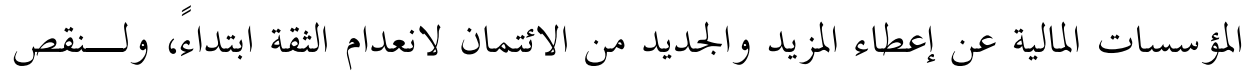

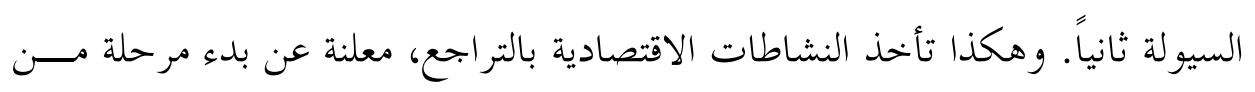

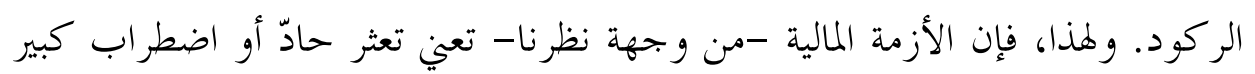

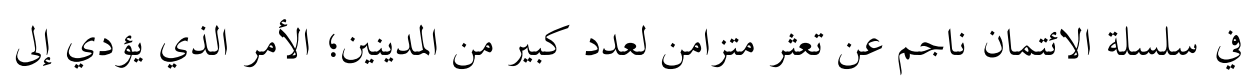

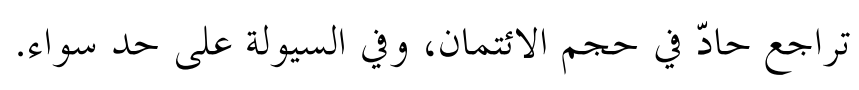




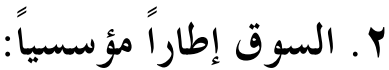

من البمحع عليه أنَّ مؤسسة السّوق بشكل عام تُعدُّ واحدة من أهــــم المؤسســـات

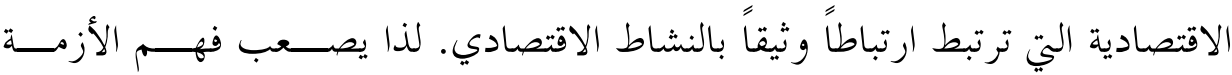

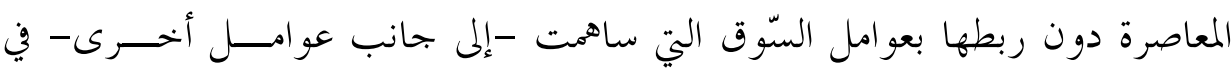

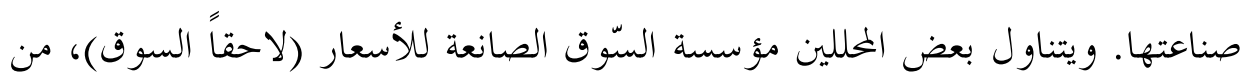

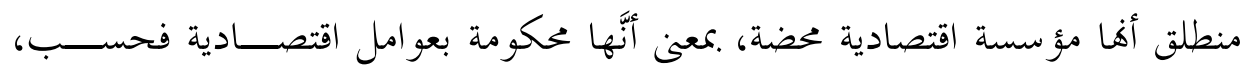

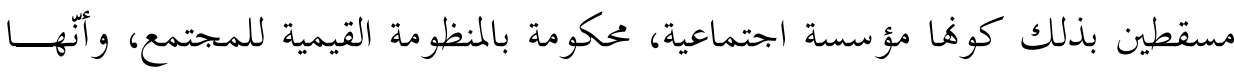

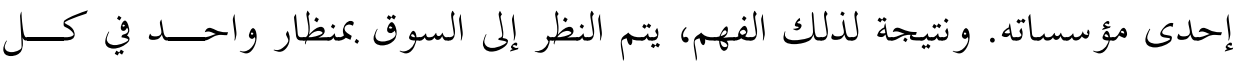
الأنظمة الاقتصادية، فيسمح بعض المحلين لأنفسهم سحب الحلكم الذي يصدرونه على

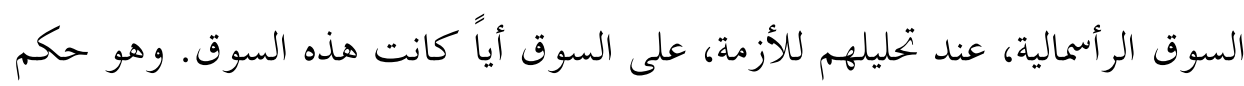
يفتقر إلى الدقة والموضوعية العلمية.

ووما عزز الفهم الخاطئ أنَّ بعض المحللين يعزو تفوق النظام الاقتصادي الرأسمــالي

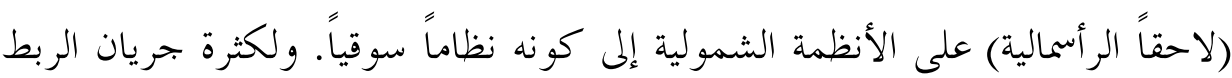

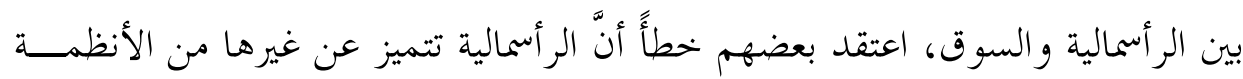

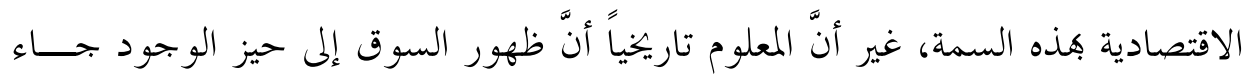

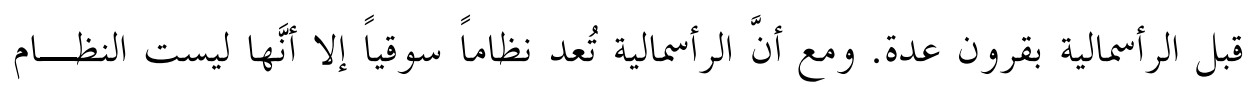

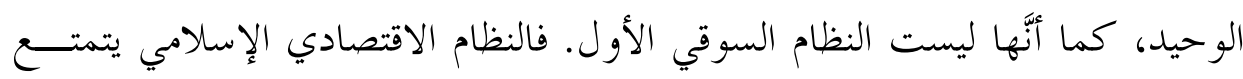

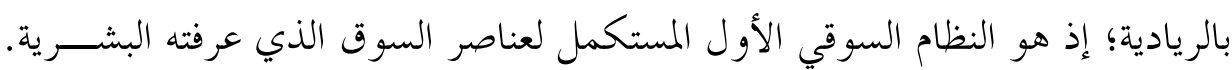
فالسوق في الدولة الإسلامية تمتعت بكل خصائص السوق اللازمة لصناعة الأسعار من وجهة نظر اقتصادية'؟ إن.

${ }^{2}$ Oran, Ahmad. Islamic State's Experience and the Rise of the Market: The Challenge of the Evidence, Dirasat, Adm. Sciences, 25(1). University of Jordan, 1998, pp. r r 1-230. 


\section{r. السوق الرأسمالية نظرياً وتاريخياً:}

من المعلوم تاريخياً أنَّ المدرسة الاقتصادية الكلاسيكية آمنت بالفكرة الفزيوقراطية،

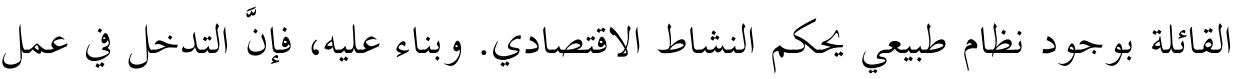
هذا النظام يفسده، وإنَّ الاختلالات التي تظهر في النظام من حين إلى آخر إنَّما مردها

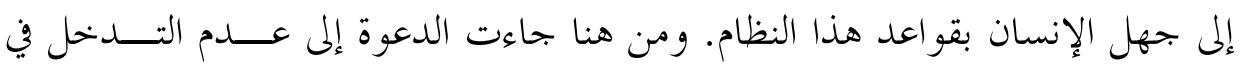

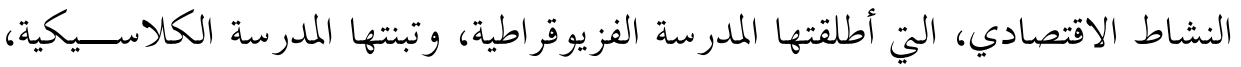
وهو ما وضع الأرضية لما بات يُعرف باقتئي اطعاد السوق الحرة.

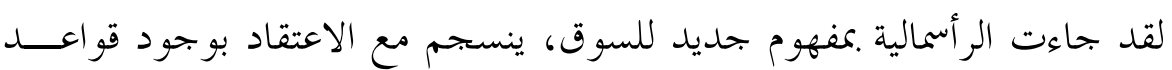

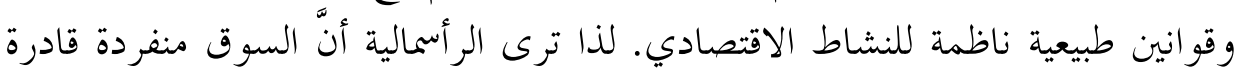

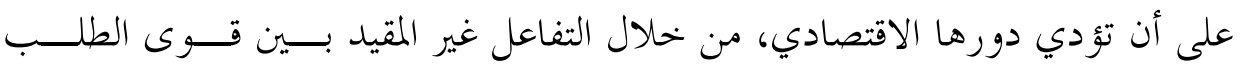

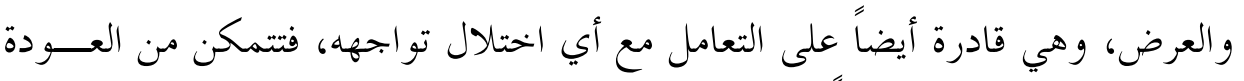

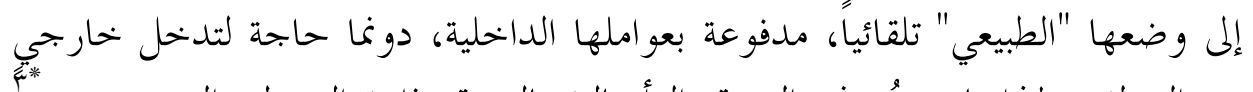

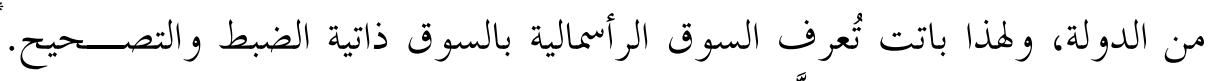

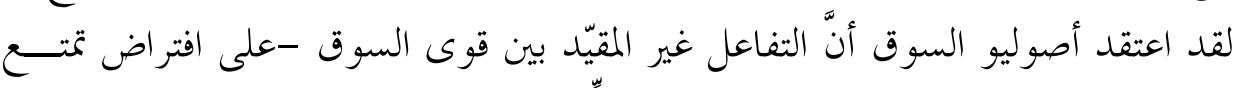

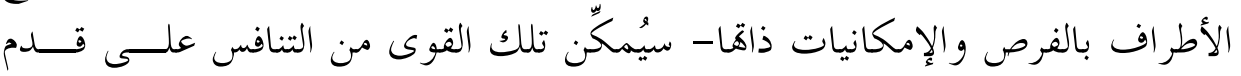

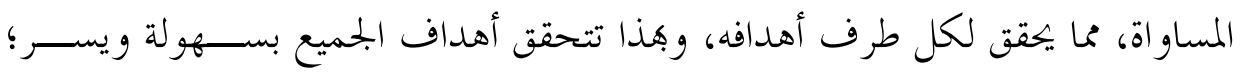
الأمر الذي لا يستوجب التدخل في ذلك التفاعل!

يستشعر الإنسان من هذه الرؤية، أنَّ النظر إلى السوق يهكمه القانون الفيزيــائي

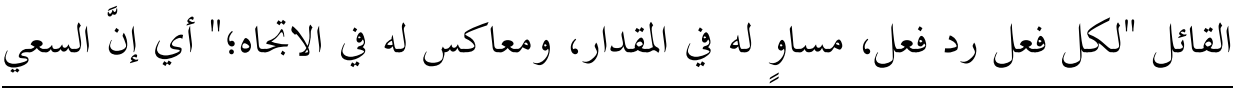

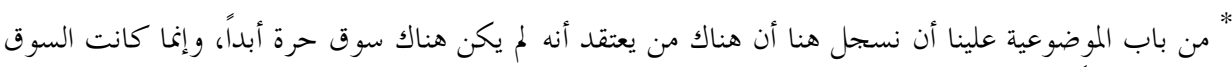

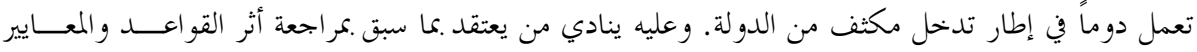

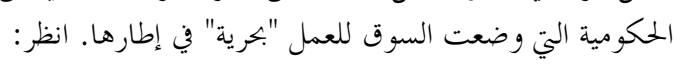

- Dowd, Kevin. Moral Hazard and the Financial Crisis, Cato Journal. 29 (1), 2009, pp. 141-166.

${ }^{3}$ Oran, Ahmad. Islamic State's Experience and the Rise of the Market: The Challenge of the Evidence, Dirasat, Adm. Sciences, 25(1). University of Jordan, 1998, pp. 221-230. 
وراء تحقيق كل طرف لمصلحته الخاصة (الفعل)، سيخضع للضبط و كبح الجماح مــن

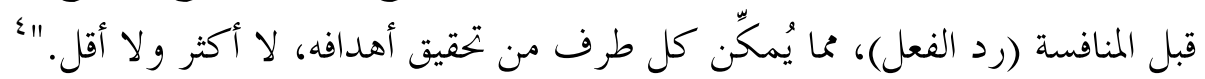

ومن المعلوم أنَّالسوق المشار إليها فشلت بشكل ذريـــع في تصــحيح مســـارها

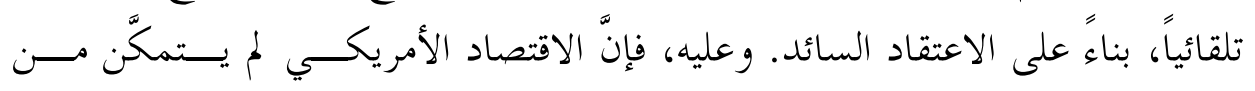

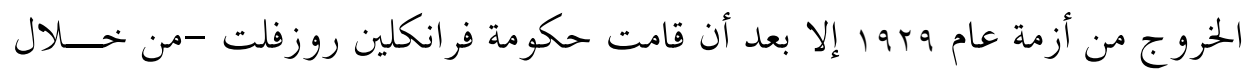

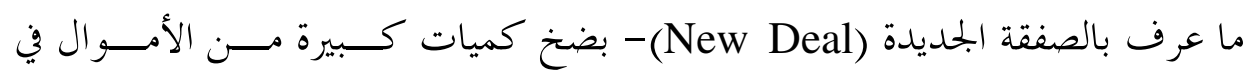

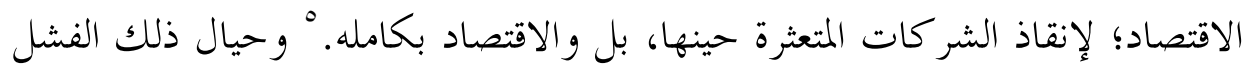

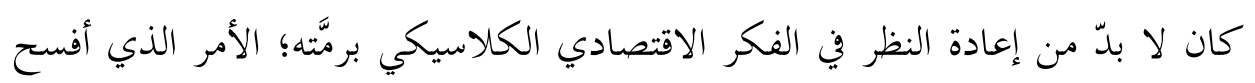

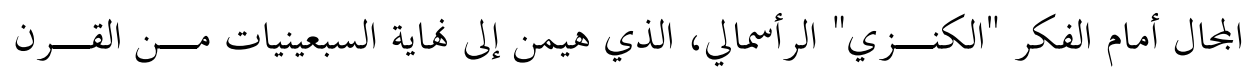

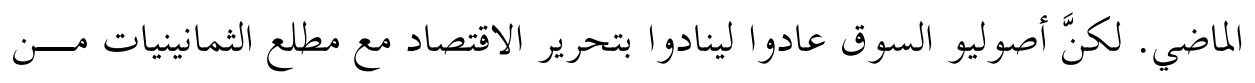
القرن الماضي، وتعزَّزت دعوةم تلك مع وصول الذين باتو ا يعرفون بالمحافظين الجحدد.

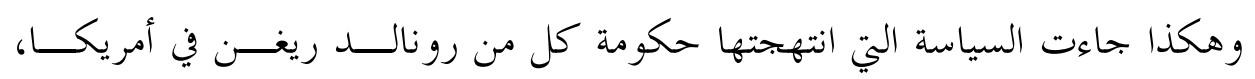

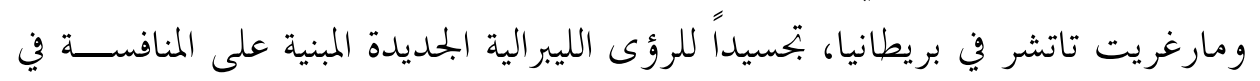

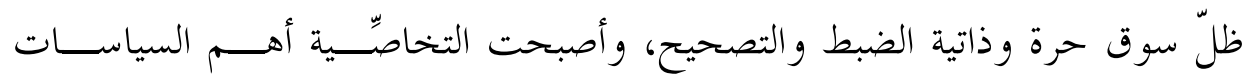

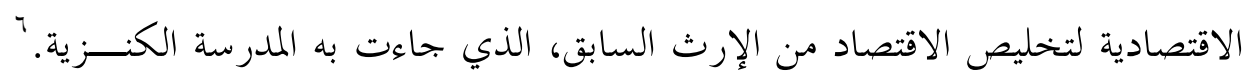

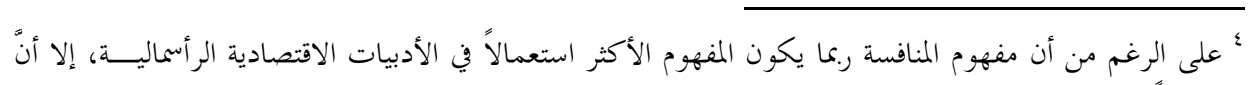

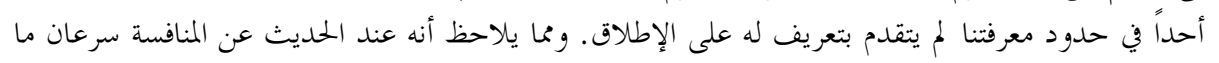

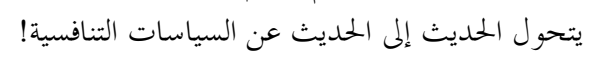

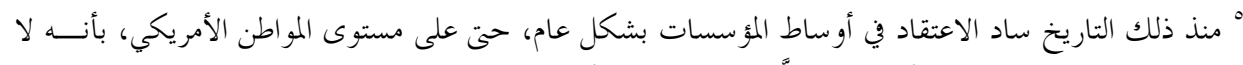

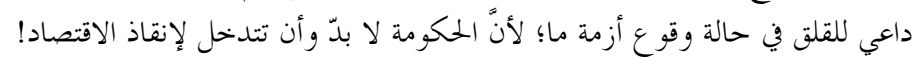

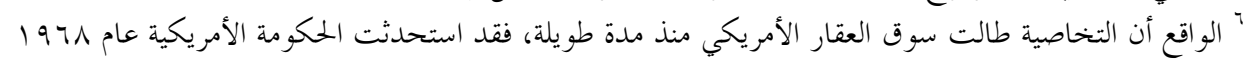

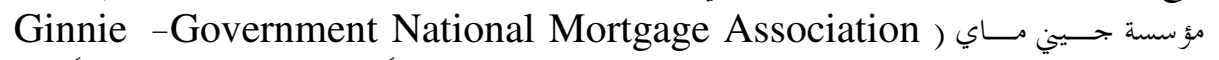
لتكون مسؤولة فقط عن جزء من القروض العقارية، المضمونة رسمياً من الدولة، التي كانت سابقاً تحت

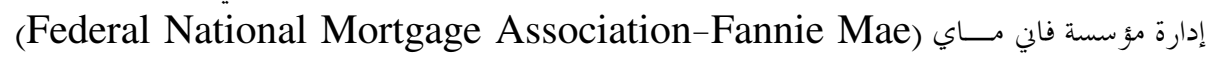

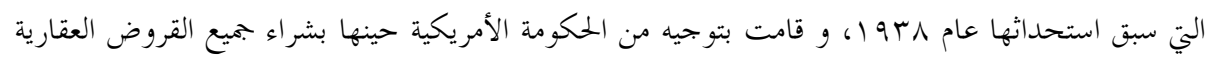

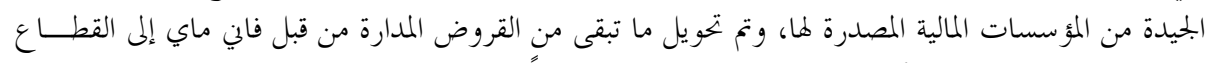

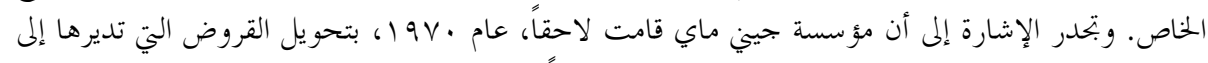

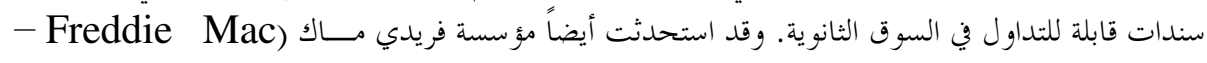

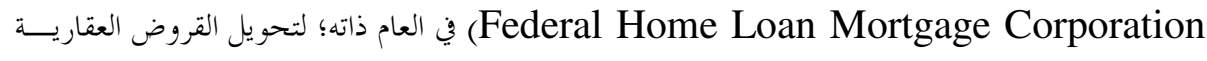


وقد أعطى سقوط المنظومة الاشتراكية دفعة قوية للفكر الليبرالي إلى درجة الاحتفـــال

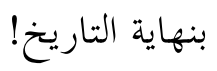

ومرة أخرى أثبتت الحرية الاقتصادية غير المقيدة فشلها الذريع، وعجزت "اليــــ

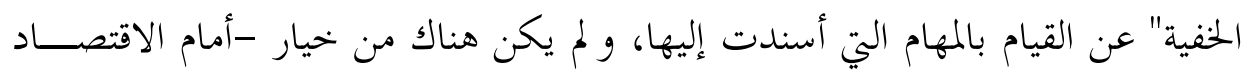

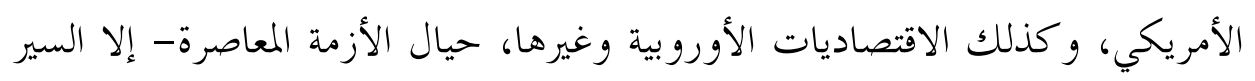

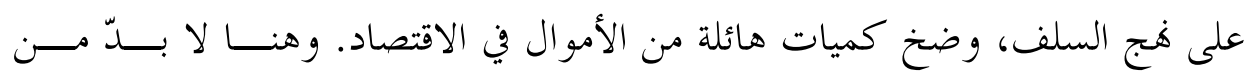

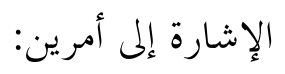

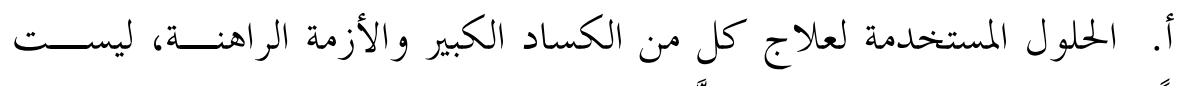

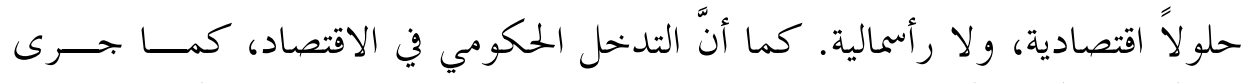

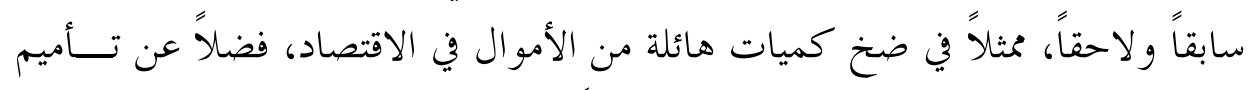

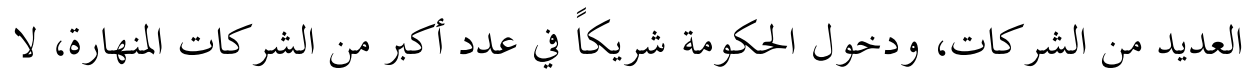

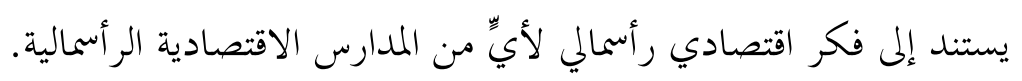

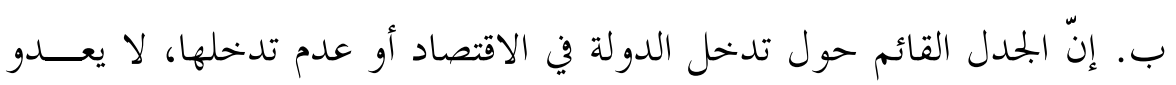

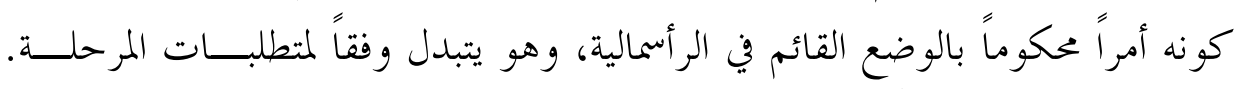

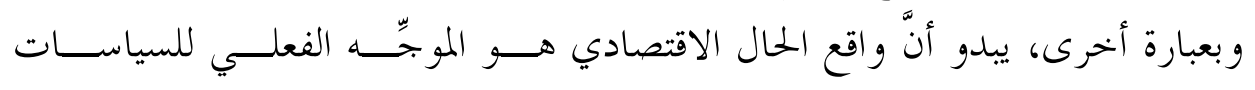

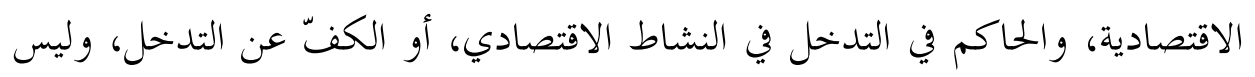

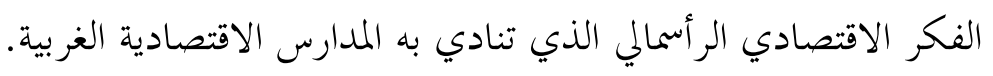

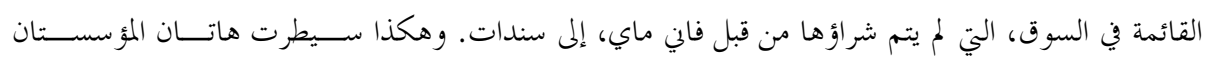

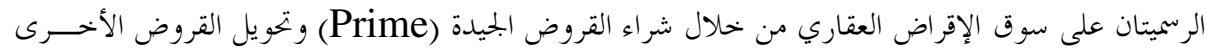

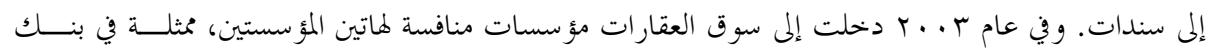

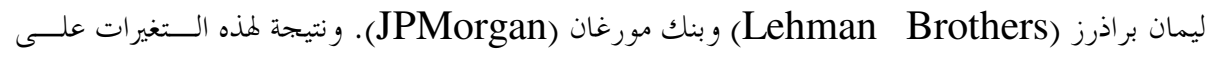

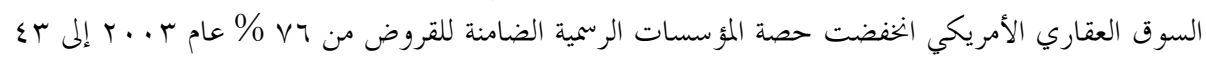

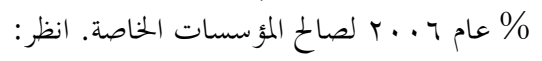

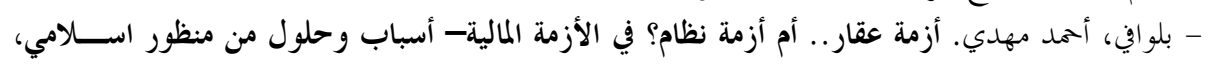

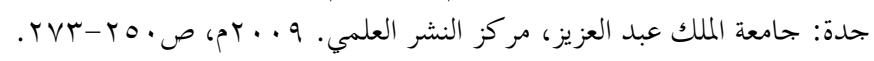

- Dowd, Kevin. Moral Hazard and the Financial Crisis, Cato Journal. 29 (1), 2009, pp. 141-166. 


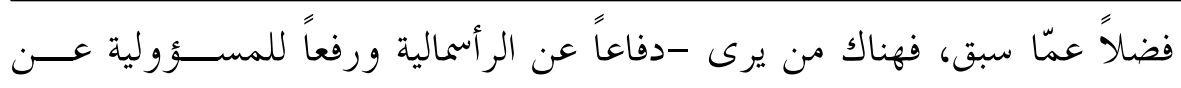

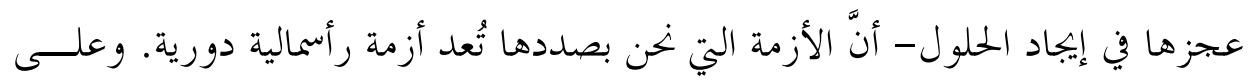

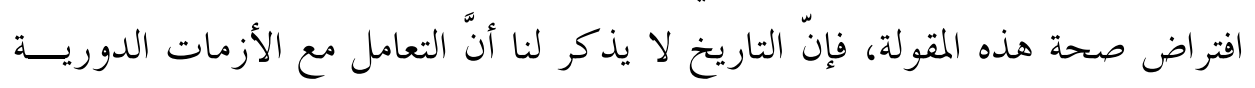

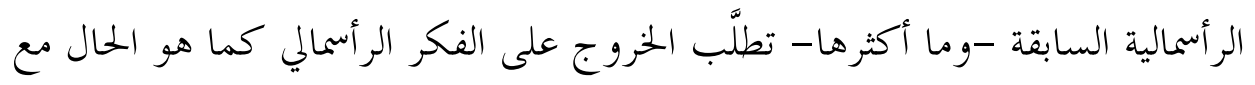

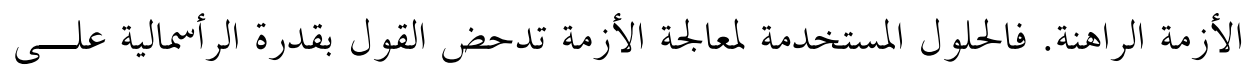

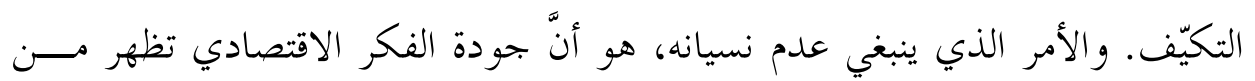

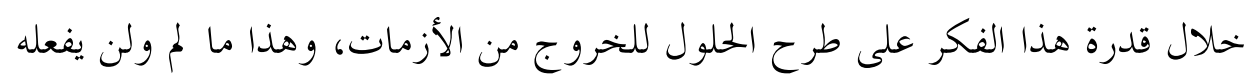

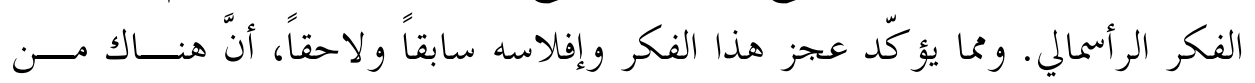

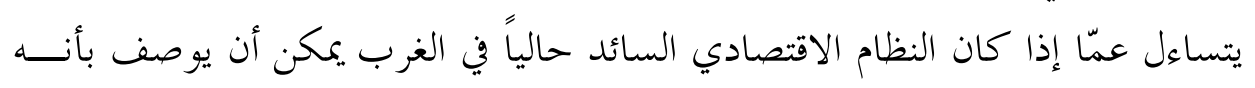
رأسمالي أصيل!

\section{ع. التحليل الرأسمالي للأزمة:}

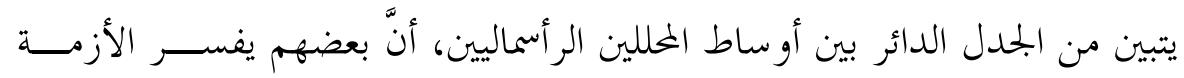

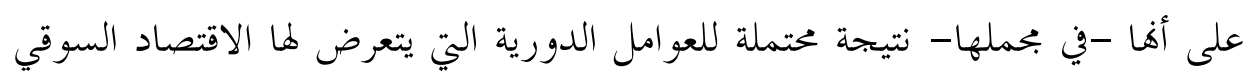

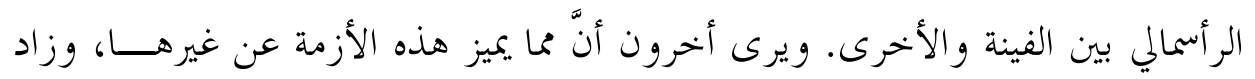

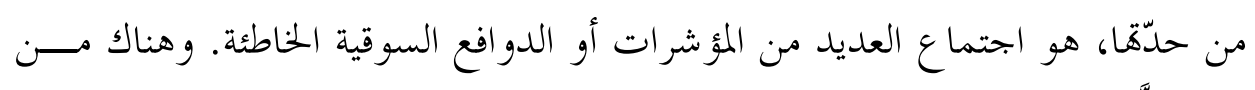

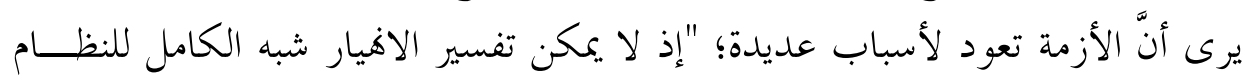

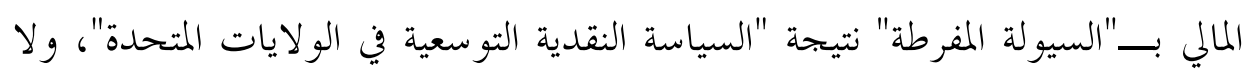

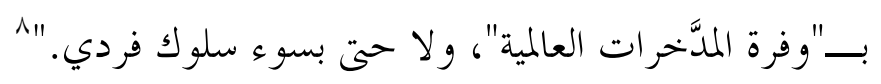

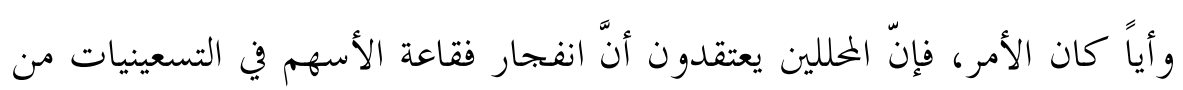
القرن الماضي في أمريكا، أدت إلى زيادة كبيرة في ثروات فئة على حساب فئة أخرى،

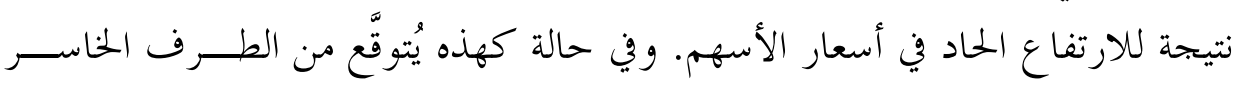

${ }^{7}$ Sen, Amartya. Capitalism Beyond the Crisis, The New York Review Books, Vol. 56, Number 5, March 26, 2009.

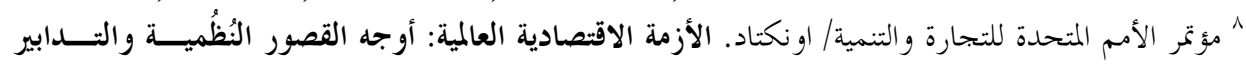

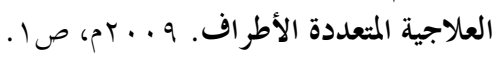




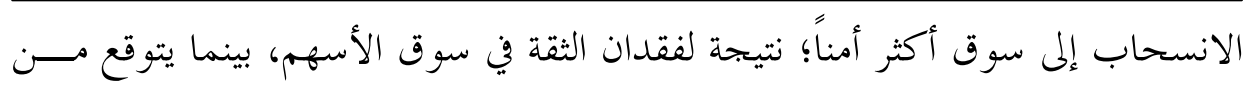

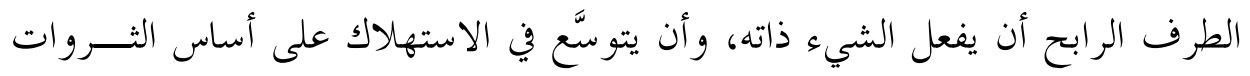

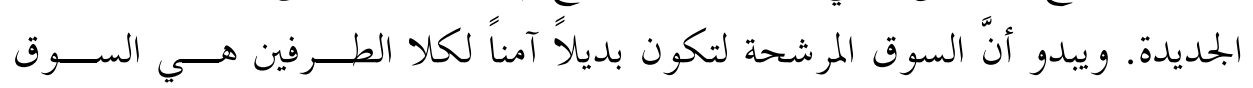

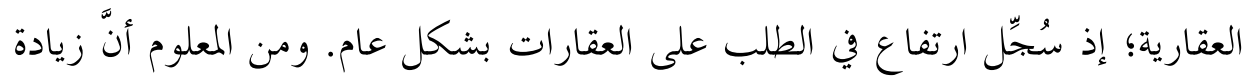
الطلب على سلعة ما سيؤدي -بشكل عام- إلى ارتفاع ملموس في سعر تلك السلعة.

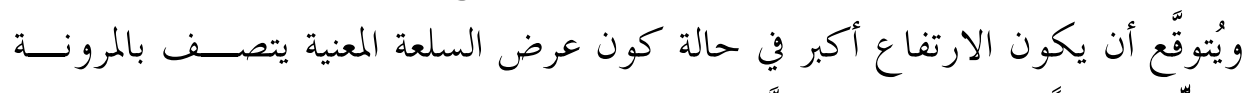

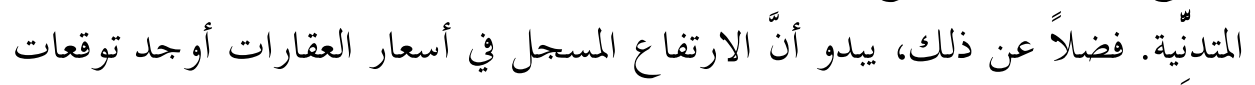

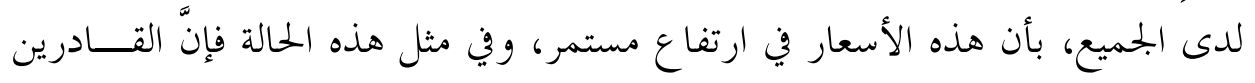

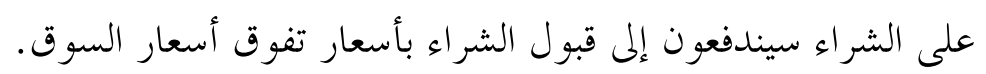

من ناحية أخرى، تشير الوقائع إلى أنَّ التوسع في الاستهلاكك في هاية التســعينيات

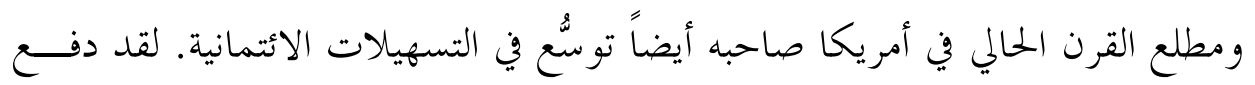
ضَعْفُ الاقتصاد الأمريكي في مطلع الألفية الثالثة بالاحتياطي الفيدرالي (البنك المركزي

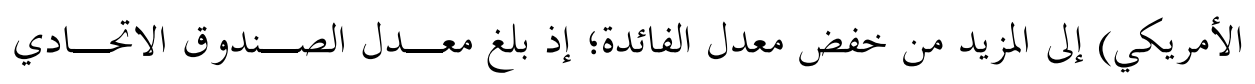
(Federal Fund Rate)

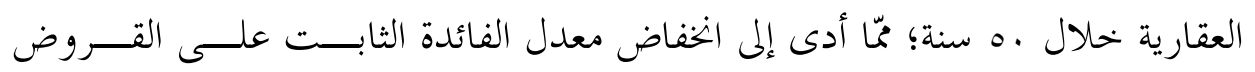

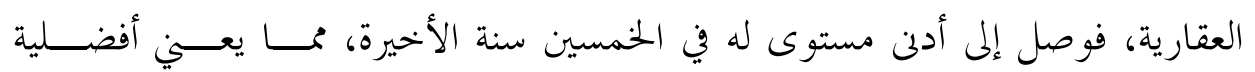

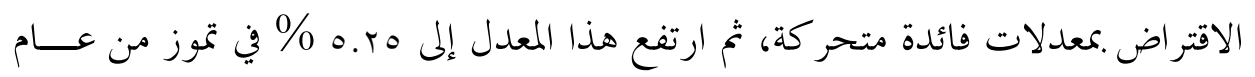

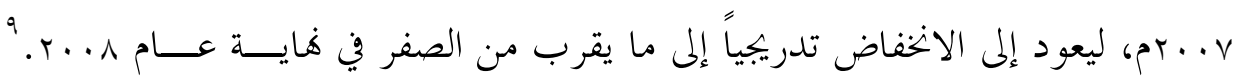
و نتيجة لذلك، ولسياسة الحكومة الأمريكية الهادفة إلى تمكين ذوي الدخول المتدنية من

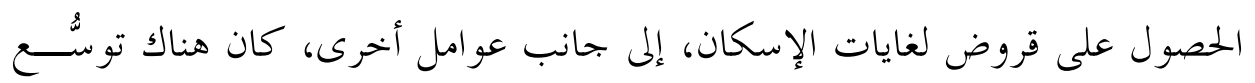

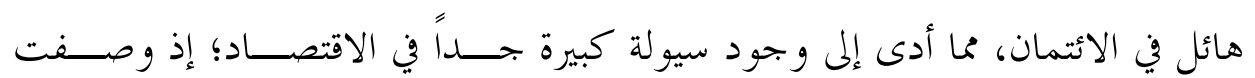
السوق بأها كانت مُغْرَة بشكل كبير بنقود رخيصة (Cheap Money).

${ }^{9}$ Baker, Dean. The Housing Bubble and the Financial Crisis, Real-World Economics Review, issue no. 46, 2008, pp.73-81. 


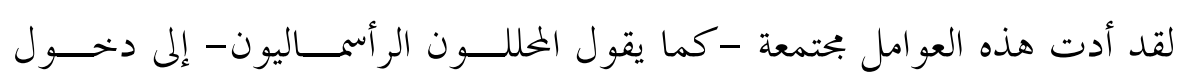

مشترين جدد إلى سوق العقارات، بنسب فاقت التوقعات، ومن بينهم متدلي ورديئسي

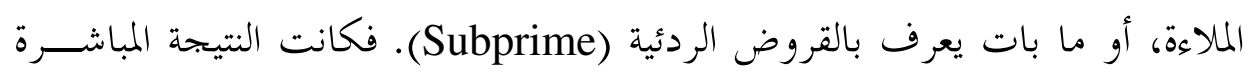
ارتفاعاً كبيراً جداً في الطلب على العقارات، مُّاّ أدى إلى ارتفاع الأسعار بنسب كبيرة

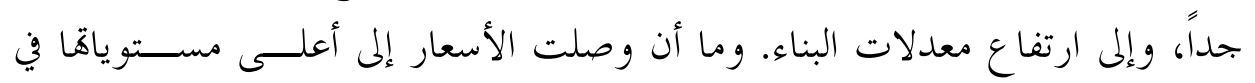

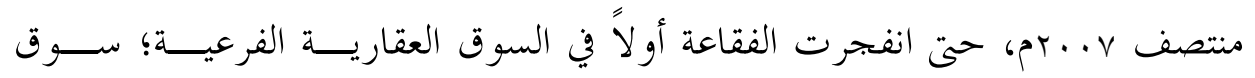

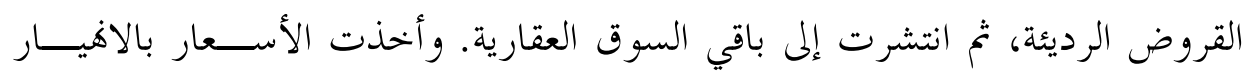

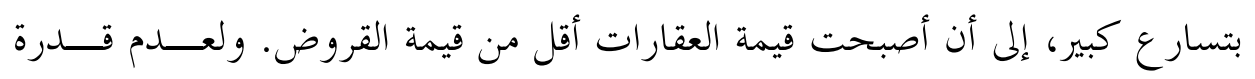

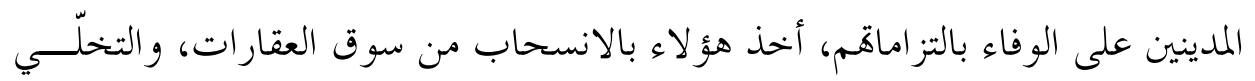

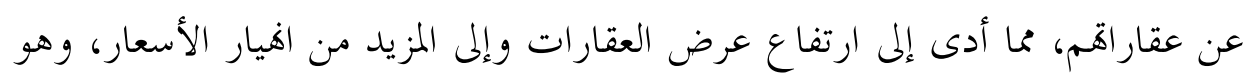

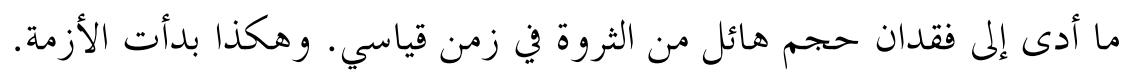

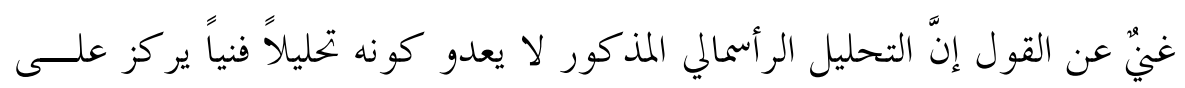

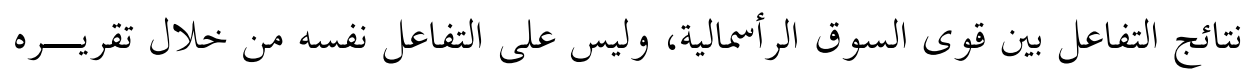
لو اقع حال الطلب و التغيرات التي طرأت عليه، وأثر ذلك في العرض، ثئ أثر كل منهما

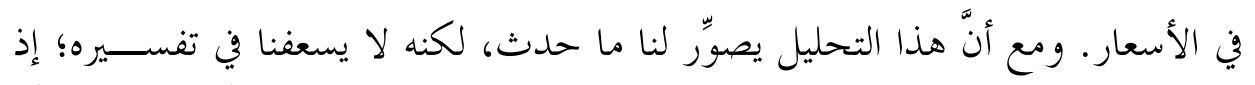

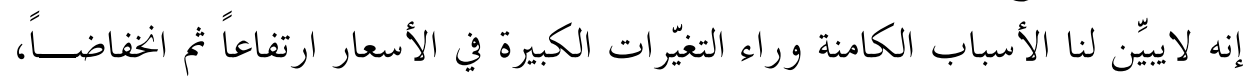

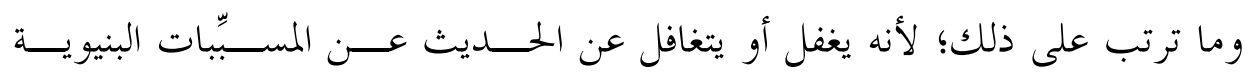
و والسلو كية.

\section{هـ الأسباب الجوهوية للأزمة:}

من المعلوم أنَّ ما يسمى بالفقاعة ليست إلا عملية مضاربة سعرية، هدف إلى رفع

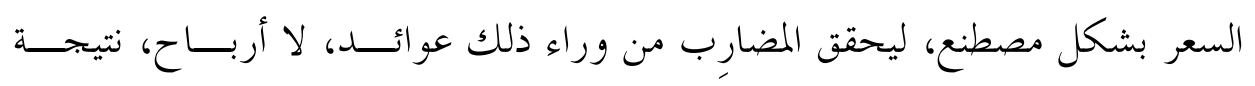

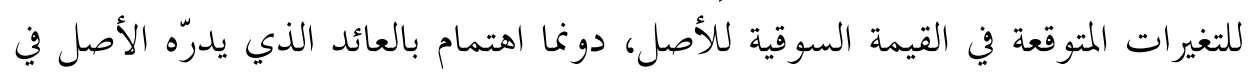

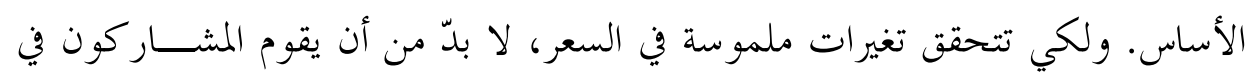

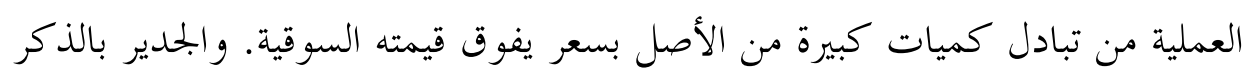


أنَّ كل مشارك يعلم أنَّ الأسعار غير حقيقية، وأهم جميعاً في مباراة (game)، وأن كلًّ

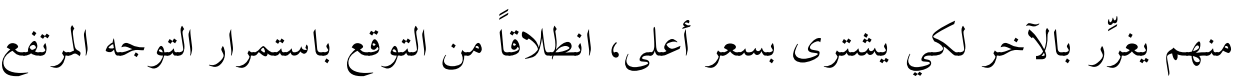

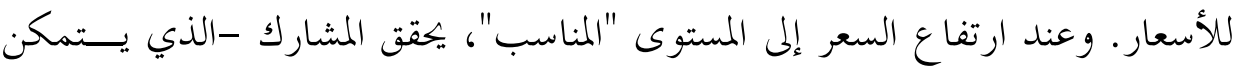

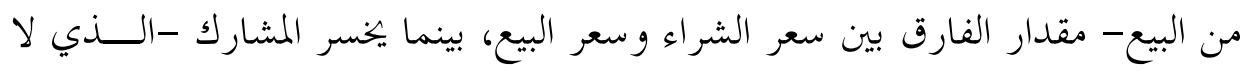
يتمكن من البيع- المقدار ذاته.

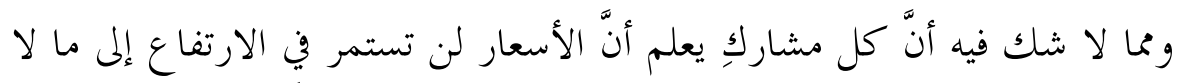

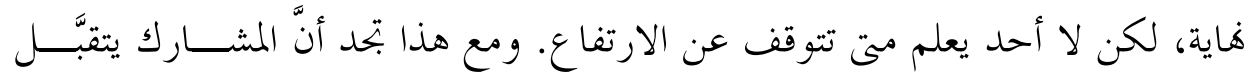

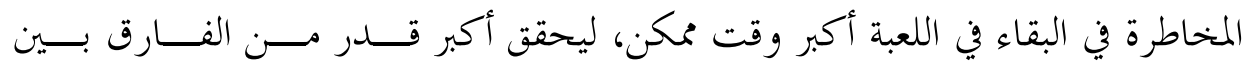

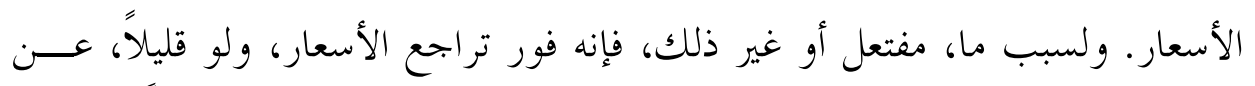

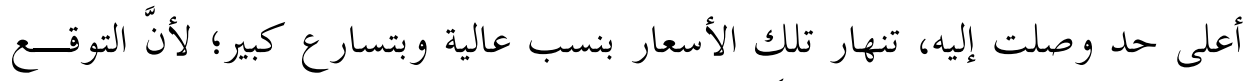

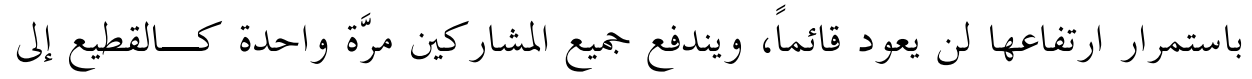

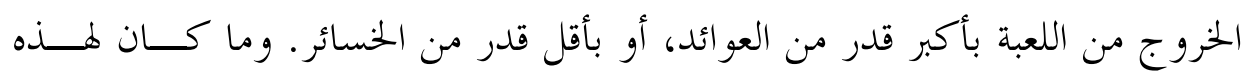

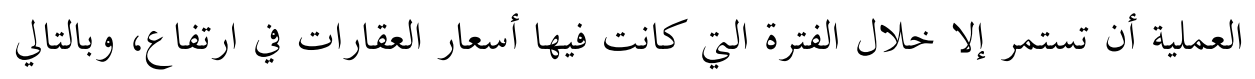

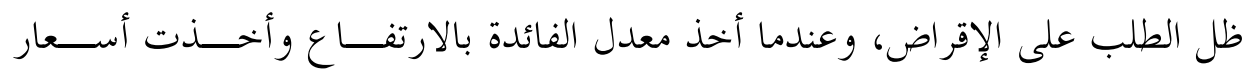

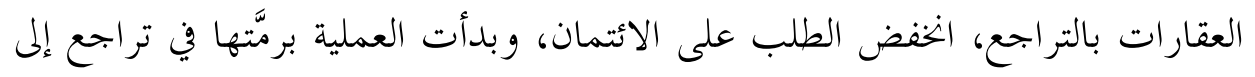

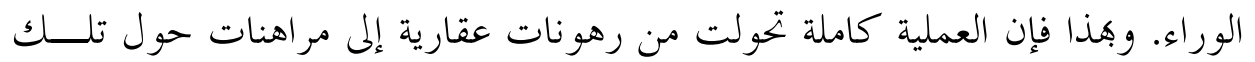
الرهونات، و بأضعاف أضعاف حجم الرهونات.

وقبل الخوض في أسباب الأزمة علينا أن نقول إنَّ بعض المحلين يخلطون عند تحليل

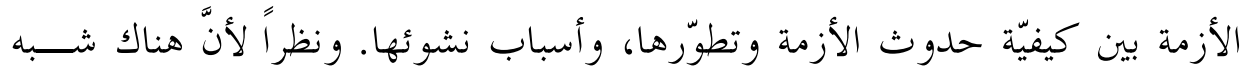

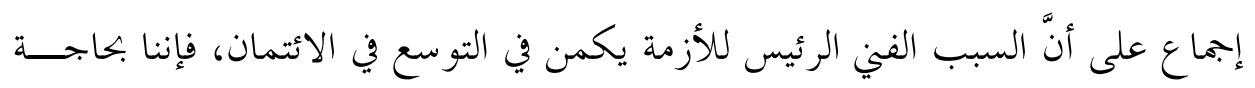

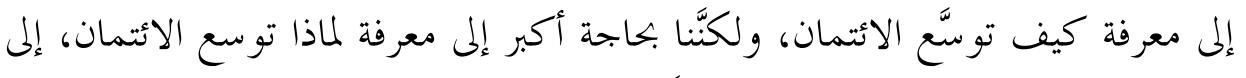

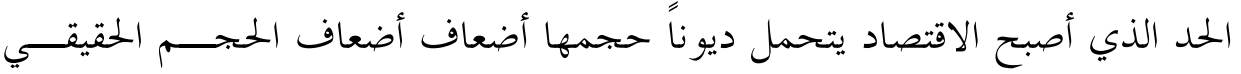
للاقتصاد.

إن النــزعة الفردية و النفعية، بل الجششع والطمع، لا بدّ وأن تــــفع إلى الفســــاد

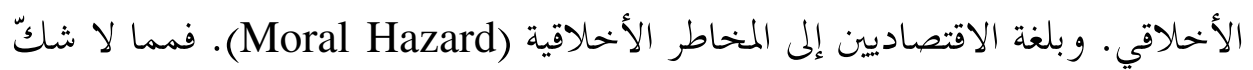




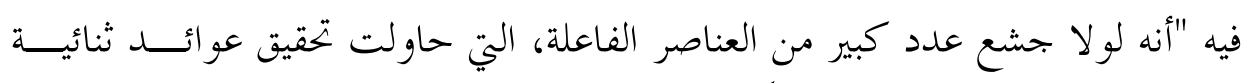

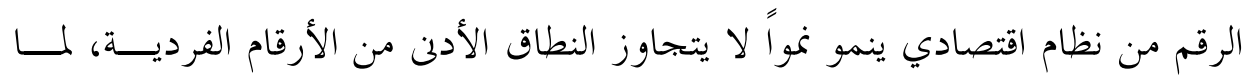

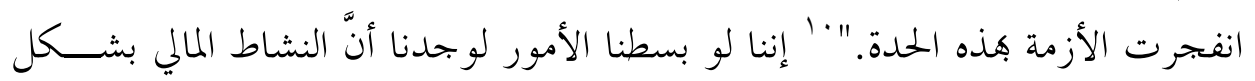

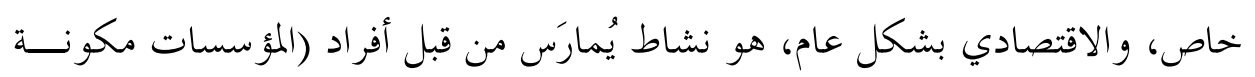

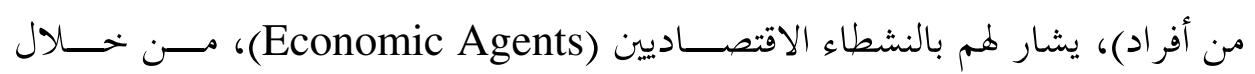

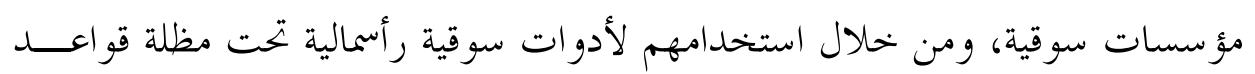

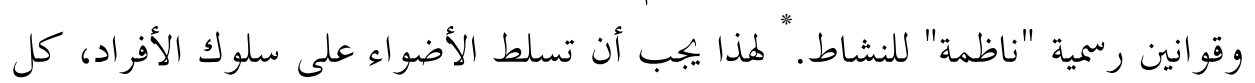

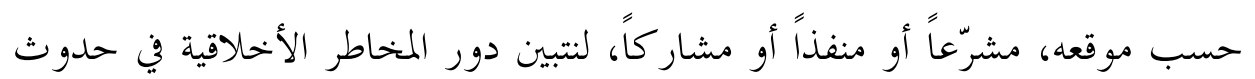
الأزمة، وهو دور رئيس، يصعب على المراقب الموضوعي بتاهله.

\section{ثانياً: مفهوم المخاطر الأخلاقية}

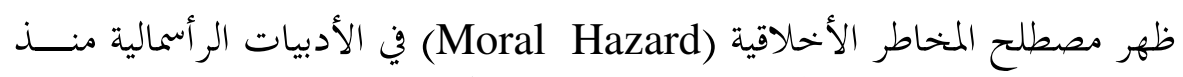

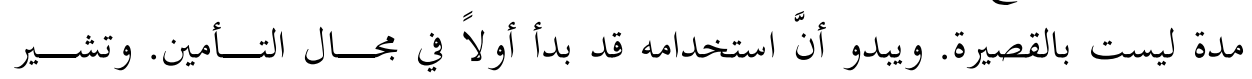

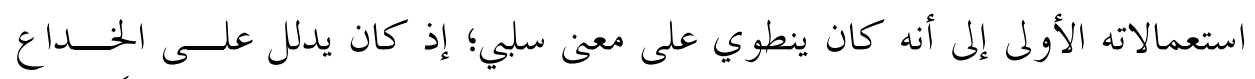

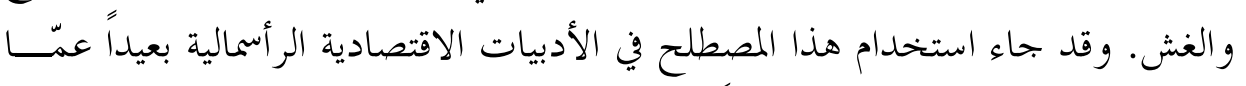

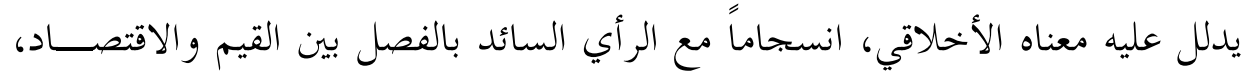

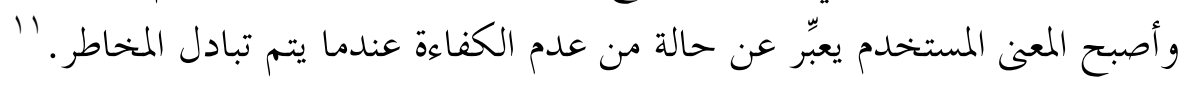
يُصا غ تعريف المخاطر الأخلاقية في المالية والإدارة والتأمين وغيرها بـــأكثر مــنـ

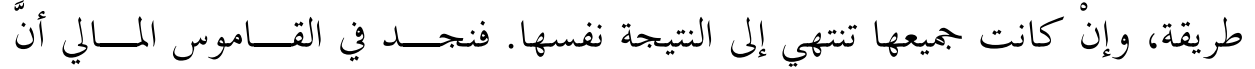

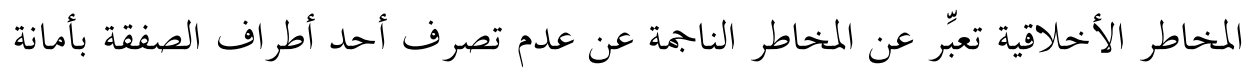

"مؤتمر الأمم المتحدة للتجارة والتنمية. الأزمة الاقتصادية العالمية: أوجه القصور النظظمية والتـــدابير العلاجيــة

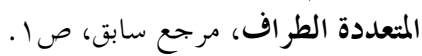

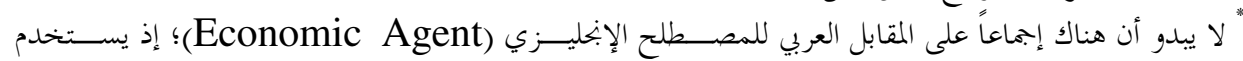

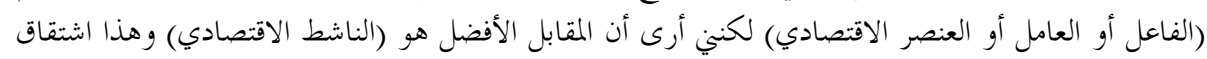

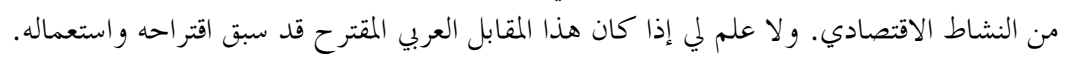

${ }^{11}$ Dembe, Allard E. and Leslie I. Boden. Moral Hazard: A Question of Morality? New Solutions. 10(3), 2000, pp. 257-279. 


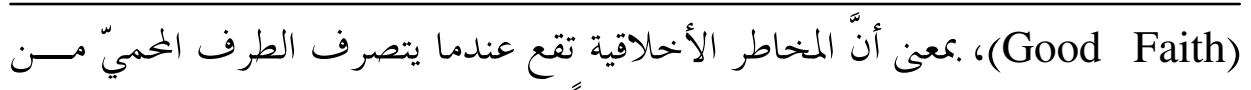

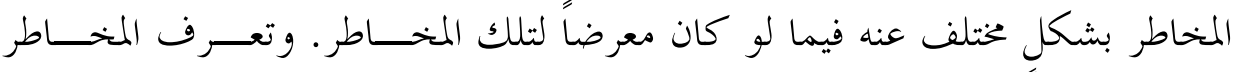

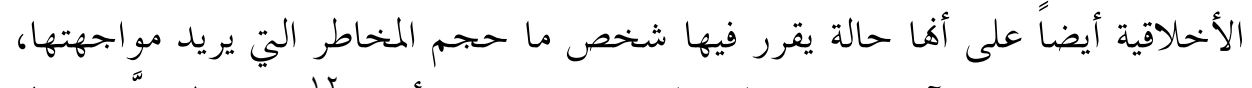

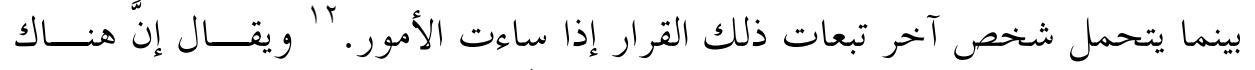

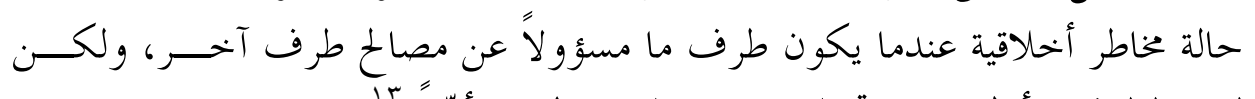

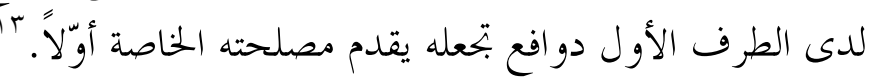

إن التفسير المعطى اقتصادياً لوجود حالة المخاطر الأخلاقية، ينطلق من وجود حالة

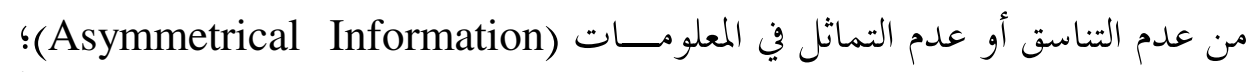

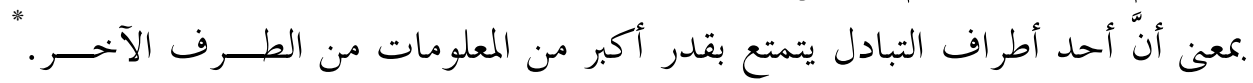

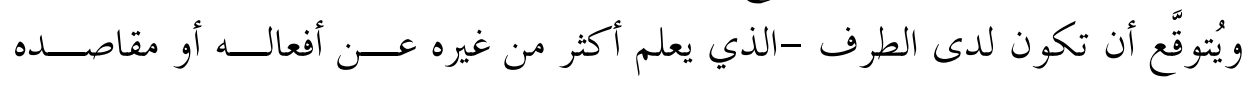

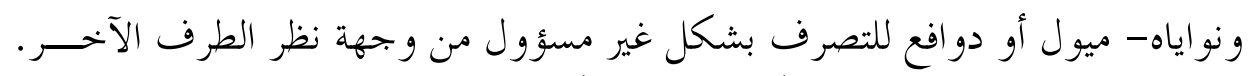

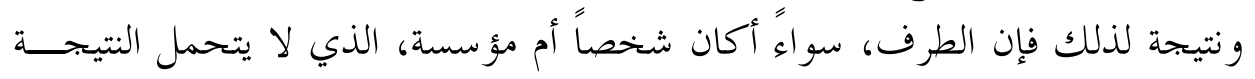

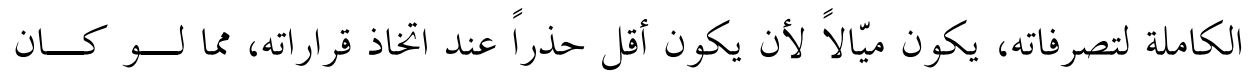

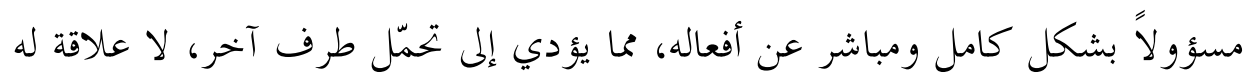

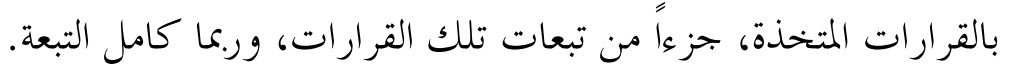

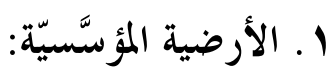

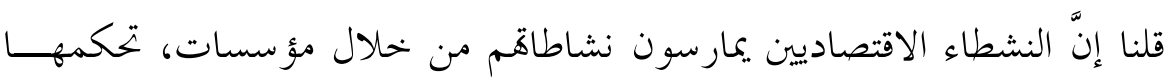

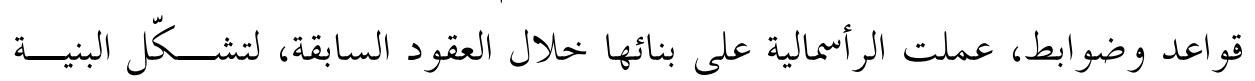

${ }^{12}$ Krugman, paul. The return of Depression Economics and the Crisis of 2008, W.W. Norton Company Limited, 2009, p. 62.

${ }^{13}$ Dowd, Kevin. Moral Hazard and the Financial Crisis, Cato Journal. 29 (1) 2009, pp. 141-166.

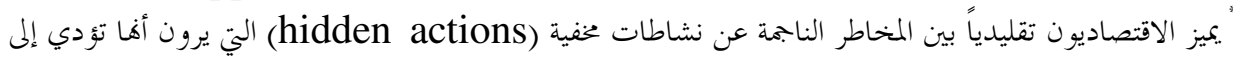

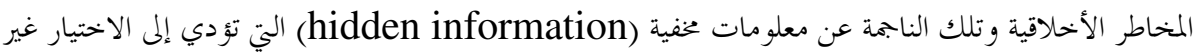

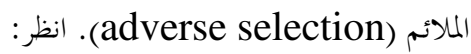

- Rauchhaus, Robert W. Principal-Agent Problems in Humanitarian Intervention: Moral Hazards, Adverse Selection, and the Commitment Dilemma, International Studies Quarterly, 53, 2009, pp. 871-884. 


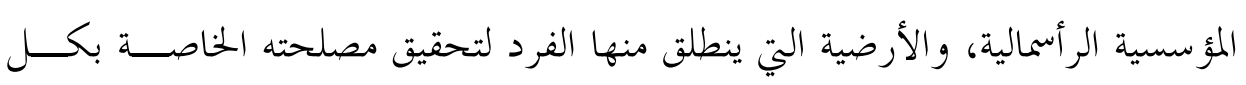

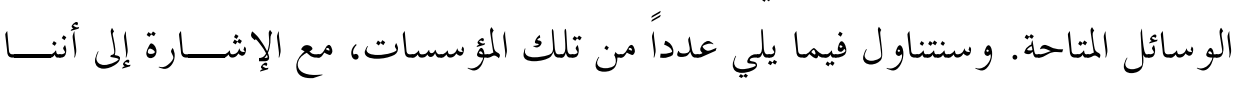

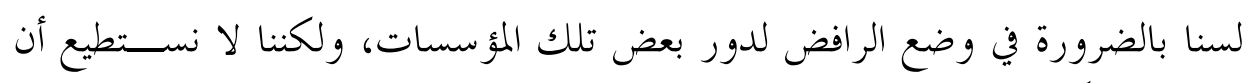

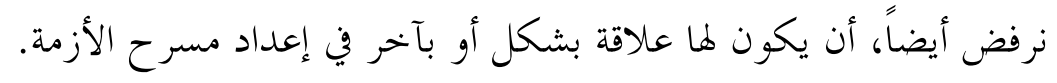

\section{أ. الانفصال بين الملكية والإدارة:}

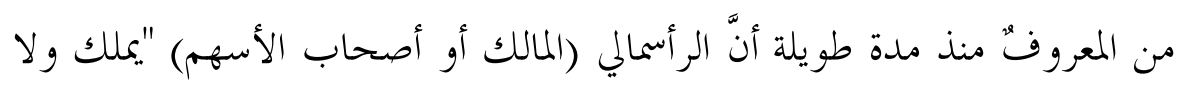

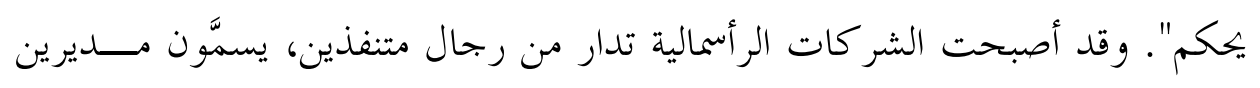

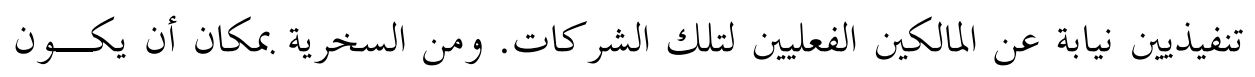

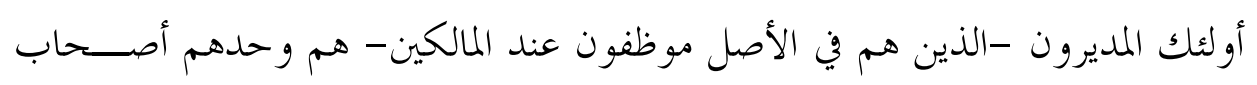

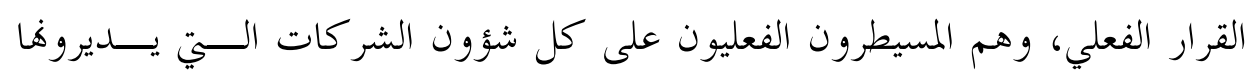

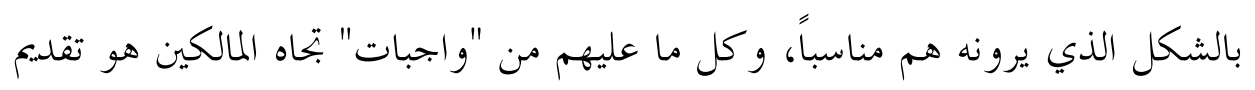

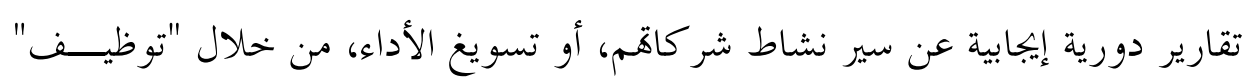

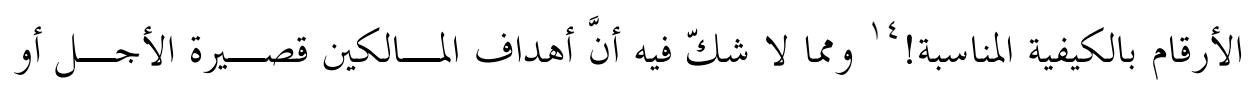

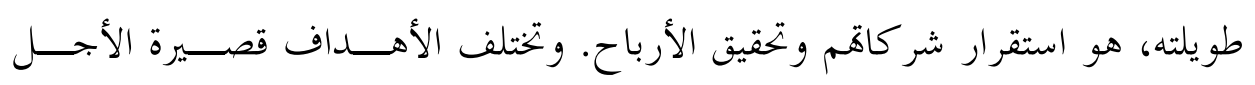

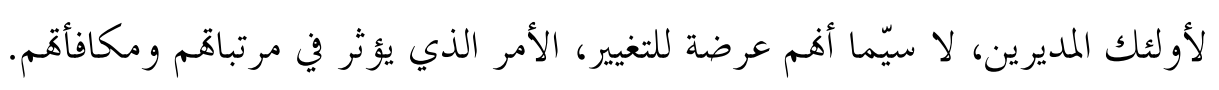

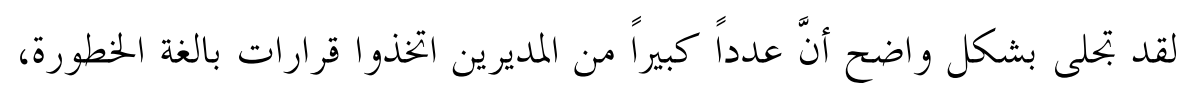

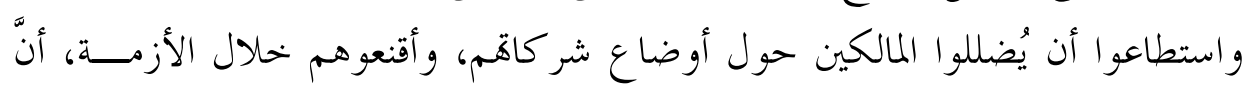

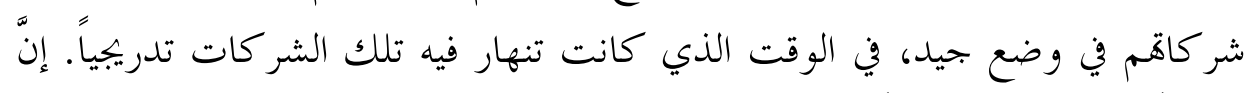

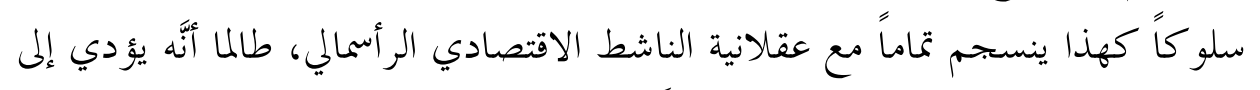

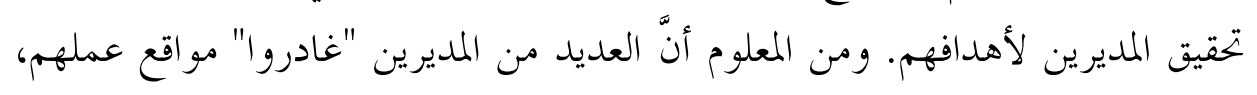

${ }^{14}$ Berliet, Jean-Pierre. Lessons from the Financial Crisis for Directors and CEOs of Insurance Companies, in "Risk Management: The Current Financial crisis, Lessons learned and Future Implication", The Society of Actuaries, 2008, pp: 33-37. 
وبعضهم يحمل عشرات من الملايين من الدولارات، بينما يحمل بعضهم الآخر المئــات

منها "مكافأة" لهم على "إفلاس" شر كاهم. 10

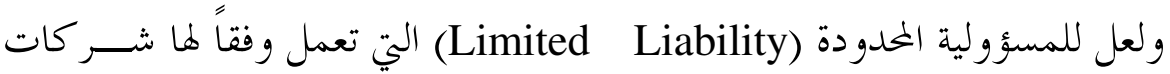

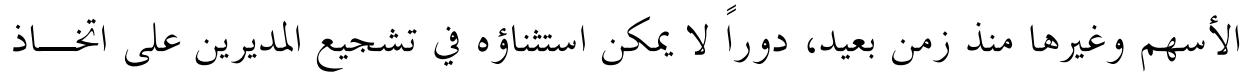

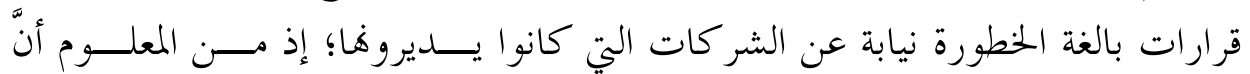

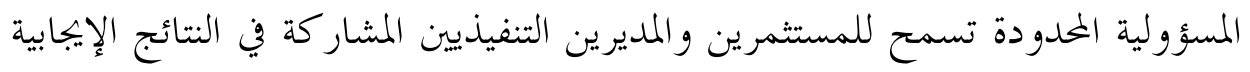

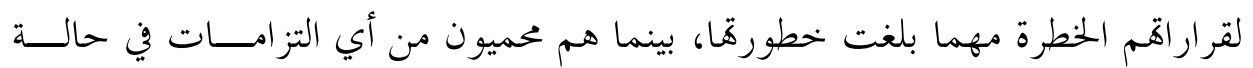

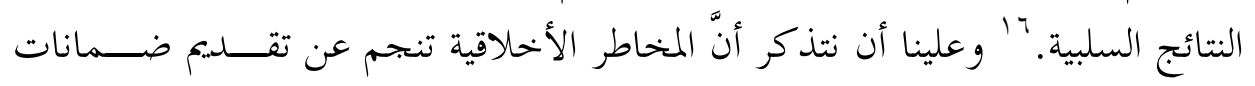
صريحة أو ضمنية، للمستثمرين عند القيام باستثماراهم.

\section{ب. غطاء الودائع والمقرض الأخير:}

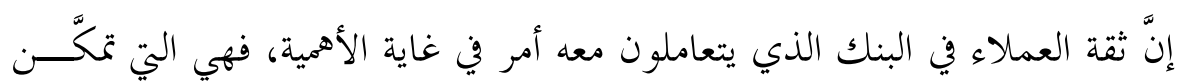

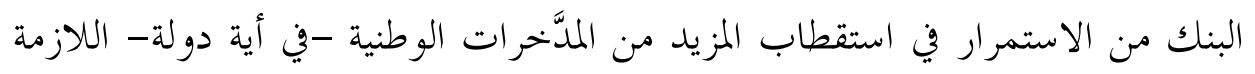

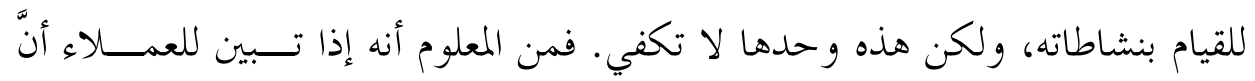

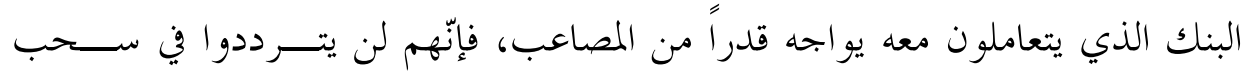

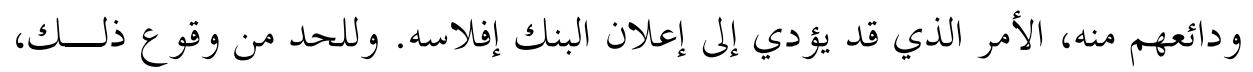

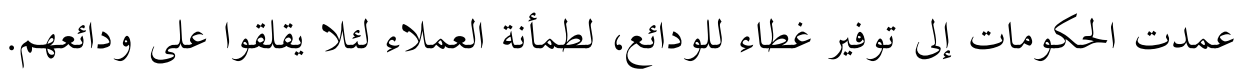

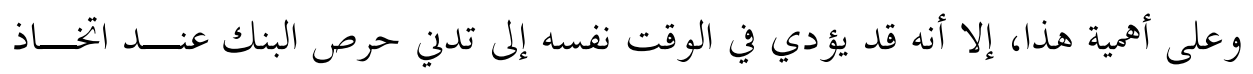

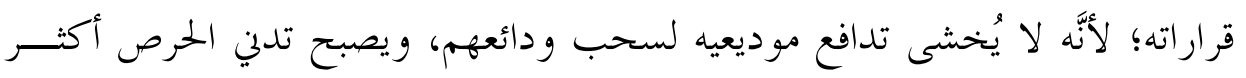

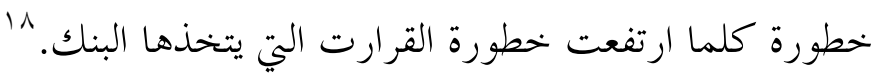

${ }^{15}$ Curtis, Gregory. The Financial Crisis and the Collapse of Ethical Behavior, White Paper no. 44, Greycourt \& Co., Inc. 2008, p. 13.

${ }^{16}$ Dowd, Kevin. Moral Hazard and the Financial Crisis, Cato Journal. 29 (1), 2009, 141-166.

${ }^{17}$ O'Driscoll Jr., Gerald P. Asset Bubbles and their Consequences, Cato Institute, no. 103, 2008, p. 2.

${ }^{18}$ O'Driscoll Jr., Gerald P. Asset Bubbles and their Consequences, Cato Institute, no. 103, 2008, p. 2. 


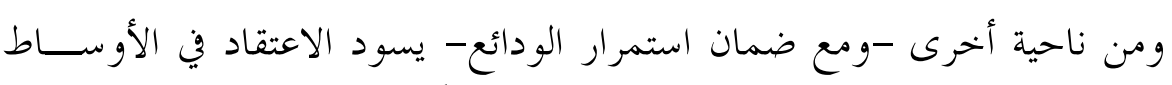

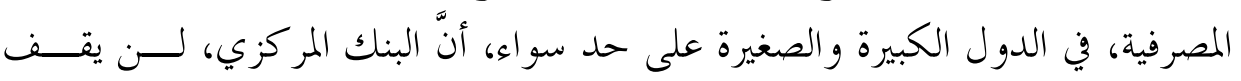

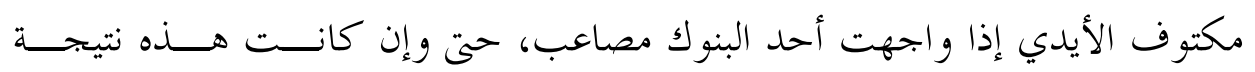

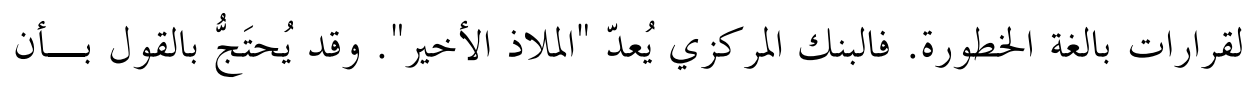

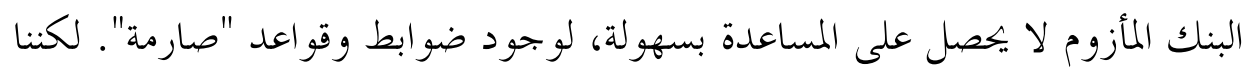

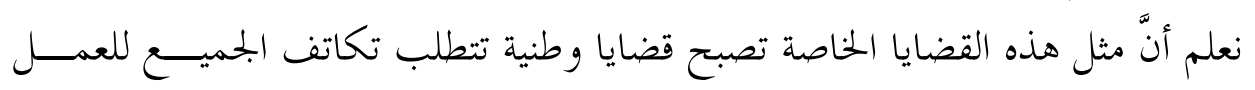

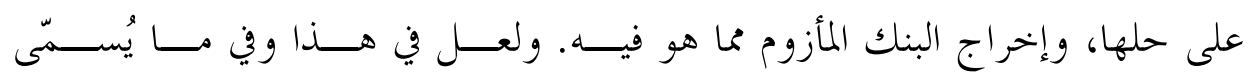

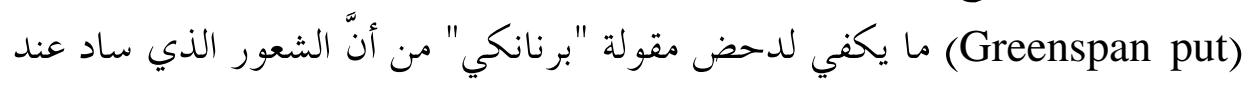

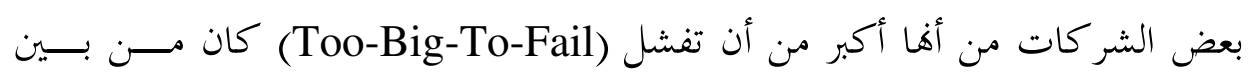
العوامل المهمة في صناعة الأزمة. 19

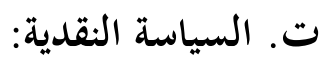

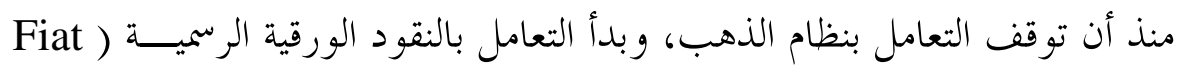
Money

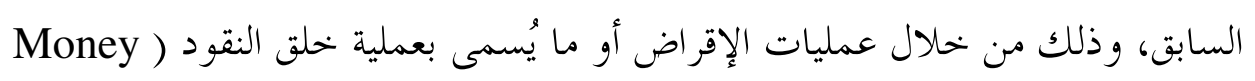
Creation

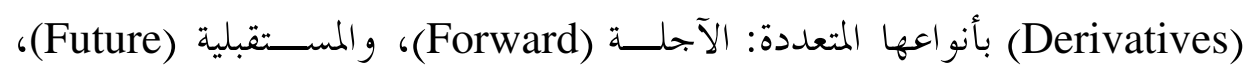

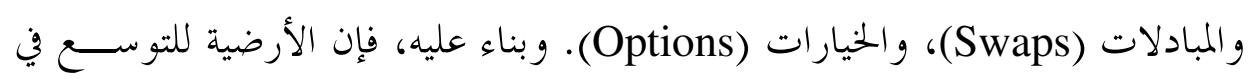

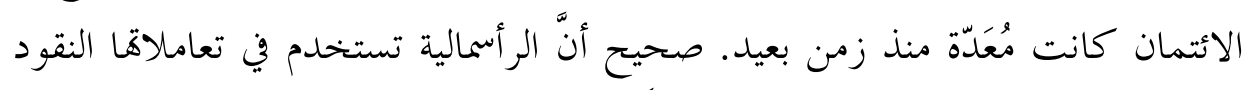

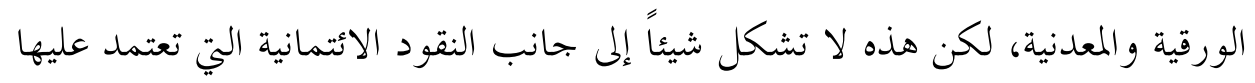

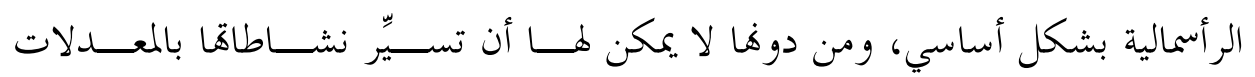

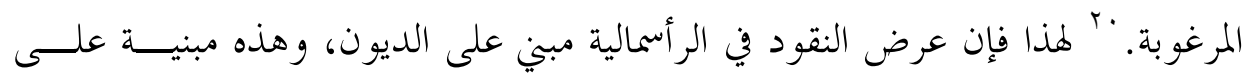

${ }^{19}$ Bernanke, Ben S. The Financial Crisis and Community Banking, BIS Review, 34, 2009, p. 4.

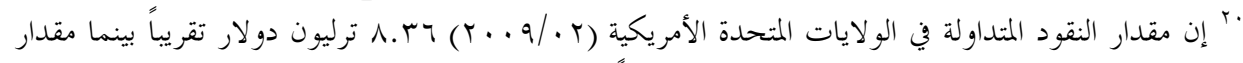

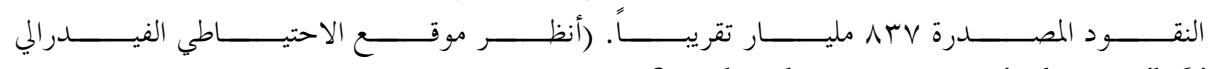

WwW.ferederalreserve.gov./releases/h6/ 


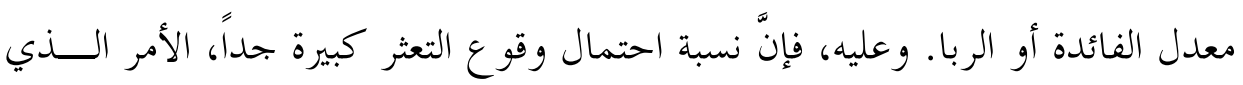

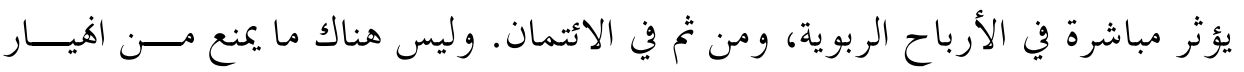
النظام في حال وقوع التعثر.

و التوسع في عملية الإقراض تعتمد على معدل الفائدة أو الربا؛ لأنه الأساس الذي

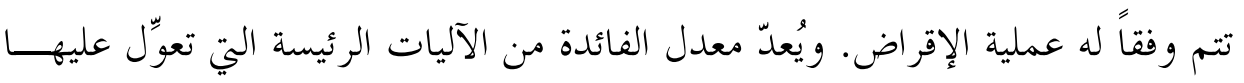
الرأسمالية لتصحيح مسار الاقتصاد. و يستوي في قبول ذلك و الإقرار به دعاة الســوق

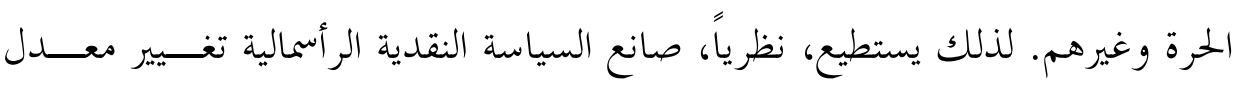

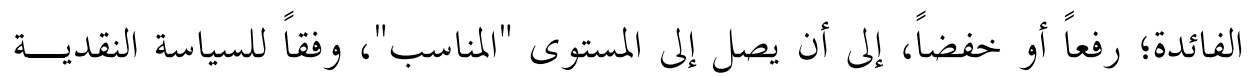
المرسومة، و القو انين الحركية، لتشجيع من يرغب في تشجيعه أو إحباط من يرغــبـ في

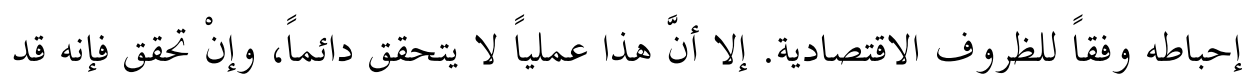

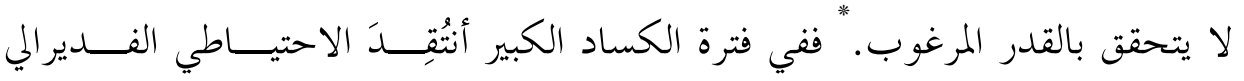
الأمريكي لاتخاذه سياسة نقدية انكماشية؛ أي معدلات فائدة مرتفعة، بينما في الأزمـــة

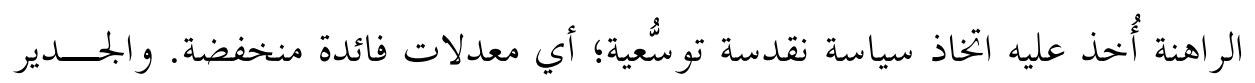
بالذكر أنه كانت هناك سيولة كبيرة في الأسواق في كلتا الحالتين، انطلاقاً من التوسع

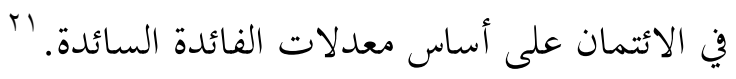
لقد تم تاريخياً تقديم تفسيرات عديدة لتسويغ استخدام معدل الفائدة، ولعل مــن أهمها "أفضلية السيولة" (Liquidity Preference) التي تقدمت بها النظرية الكنــزية؛

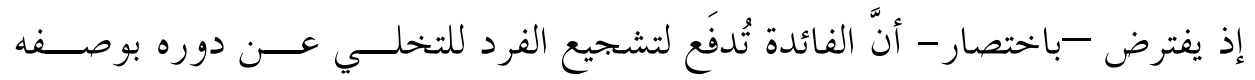

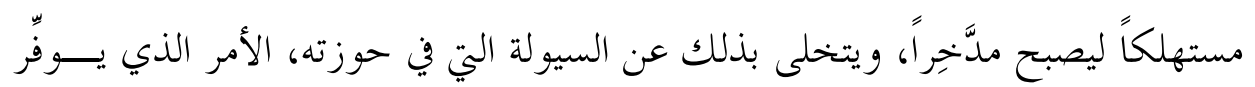
المزيد منها للمصارف التي تعمل على توفيرها لمن يرغب في الاســتثمار في الأصسـول يعلم الاقتصاديون أن السياسة النقدية تعتمد على عو امل غير قابلة للتحكم من بينها حساسية معدل الفائدة للتغير

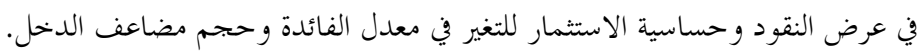

${ }^{21}$ Romer, Christina D. The Nation in Depression, Journal of Economic Perspectives, 7(2), 2008, pp.19-39. 


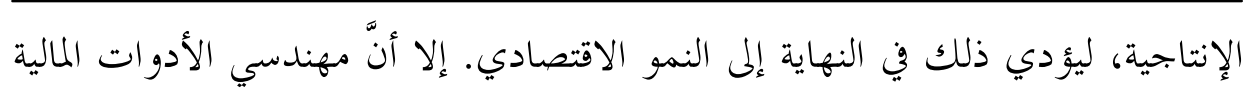

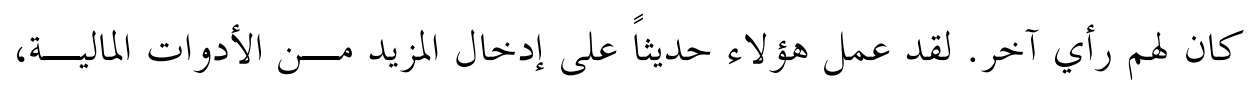

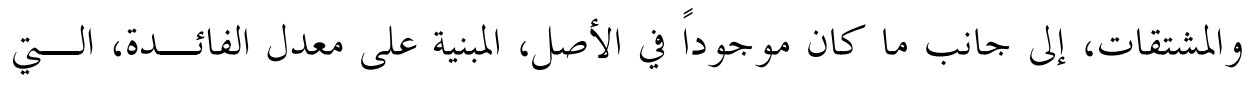

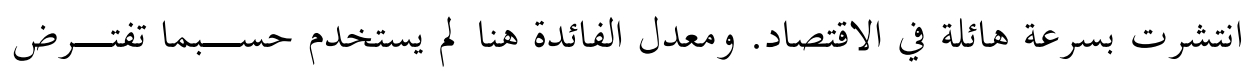

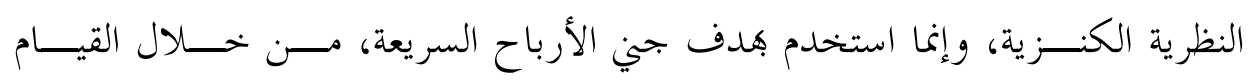

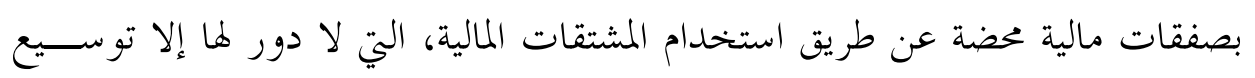

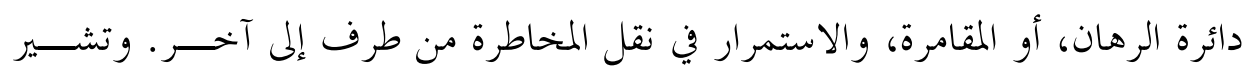

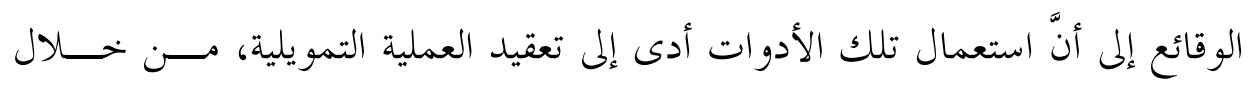

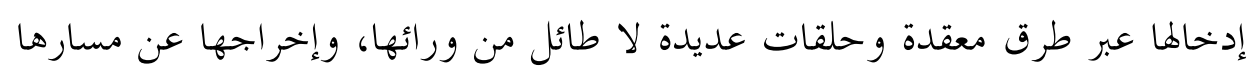
الأصلي الموجَّه نو الإنتاج.

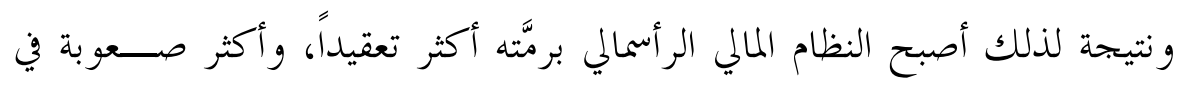

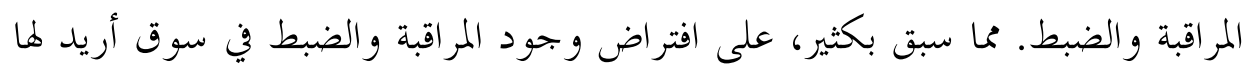

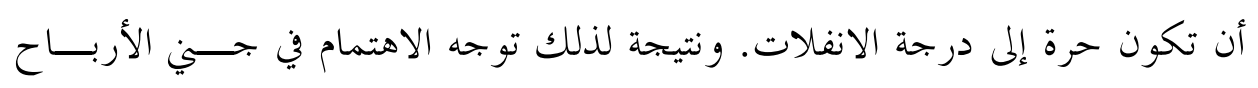

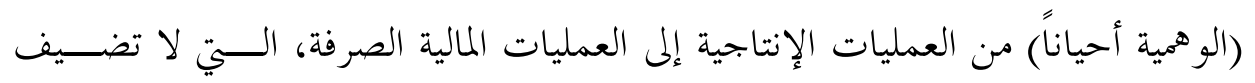

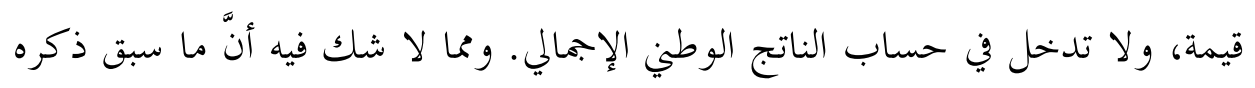

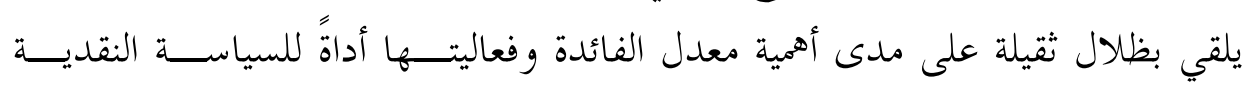

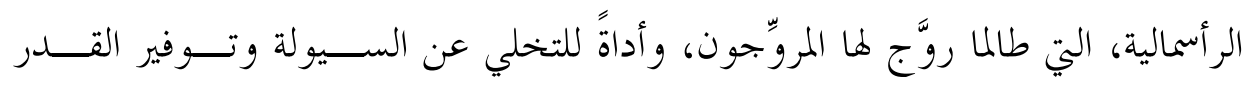

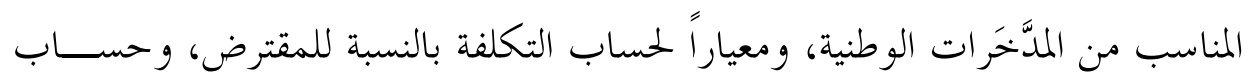

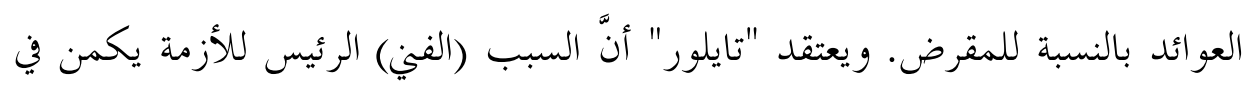

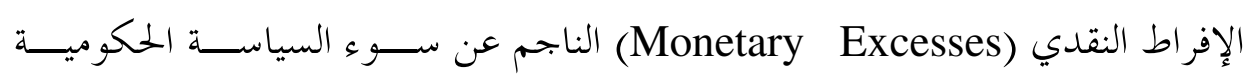

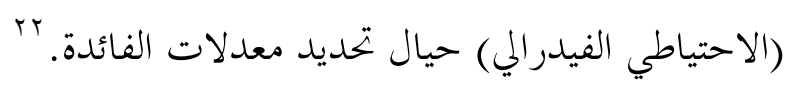

${ }^{22}$ Taylor, John B.The Financial Crisis and the Policy Responses: An Empirical Analysis of What Went Wrong, NBER working paper, no. 14631, 2009, p. 1-19. 


\section{r. دور المخاطر الأخلاقية في الأزمة:}

تبيّن أنّ الأرضية المؤسسية الرأسمالية مهيأة للناشط الاقتصادي للسعي وراء تحقيق

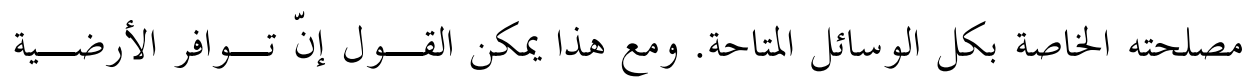

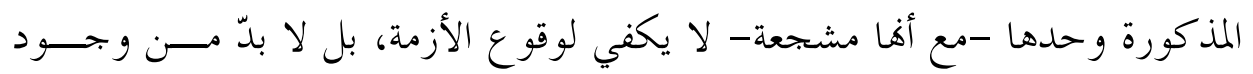

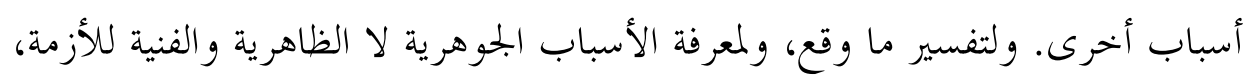

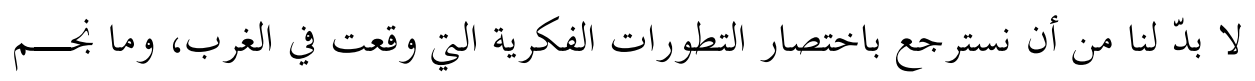
عنها.

من المعلوم أنَّ الغرب خحاض معر كة مريرة وطويلة، للتخلص من هيمنة الكنيســة

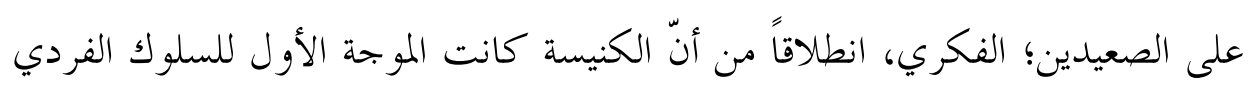

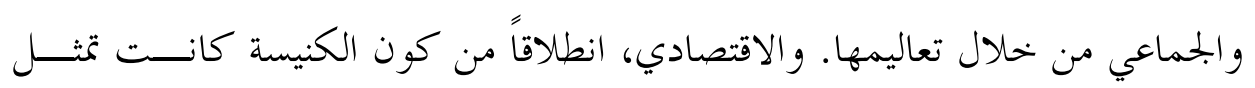

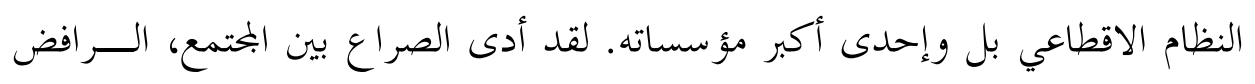

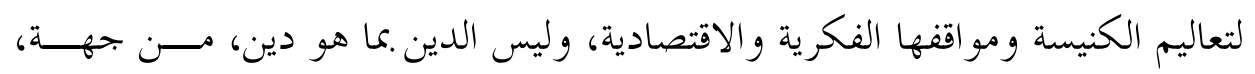

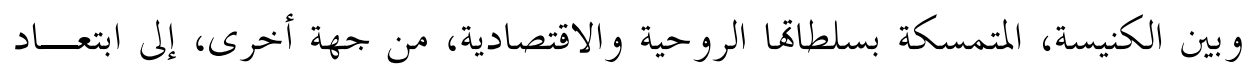

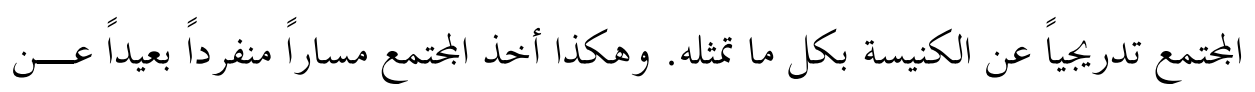
مسار الكنيسة، الأمر الذي فسره بعضنا خطاًُ بالفصل بين الدين والدولة.

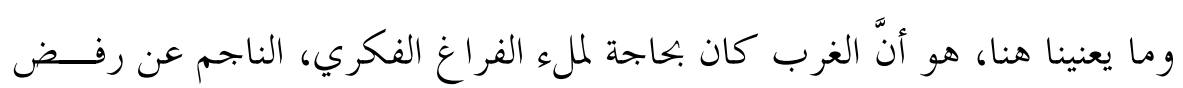

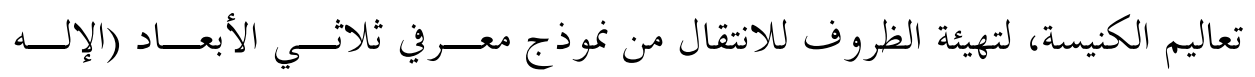

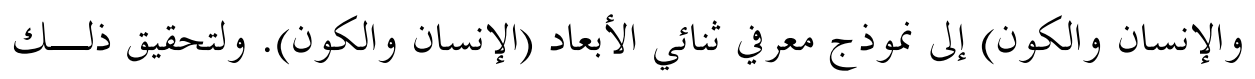

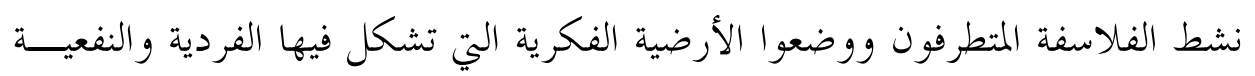

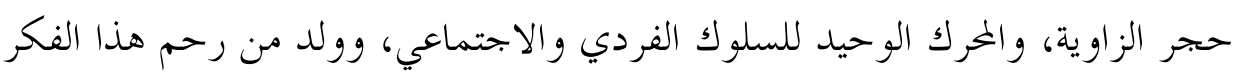

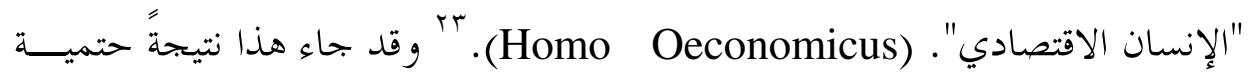
rr يُعد هذا الإنسان نمو ذجاً للاقتصادي الليبرالي الموصوف بالعقلانية التامة، والأنانية التامة، والحرية، والمنافسة، وأنه اجتماعي تام. انظر: 


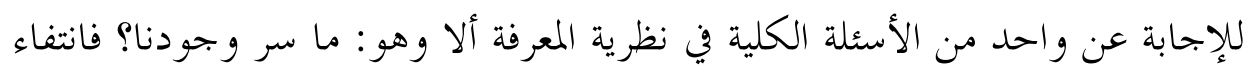

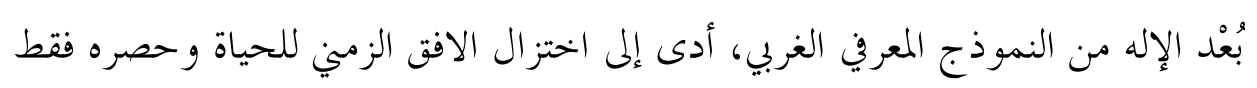

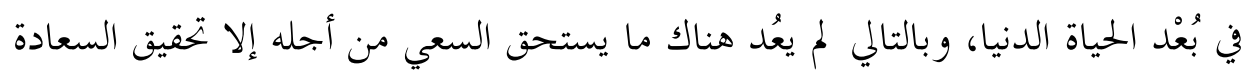

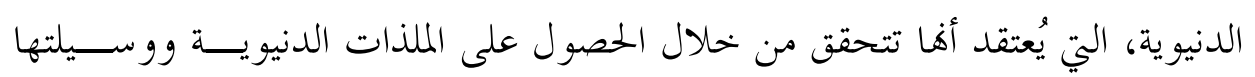

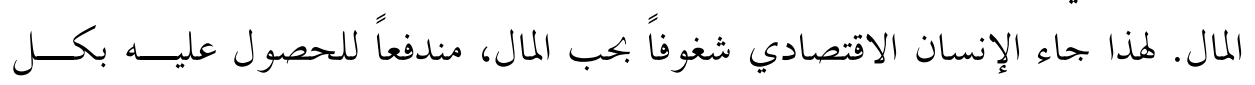

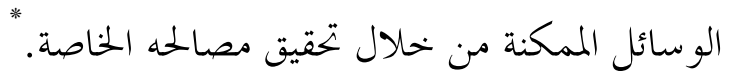

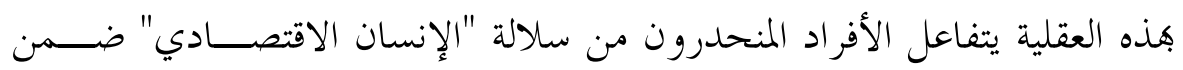

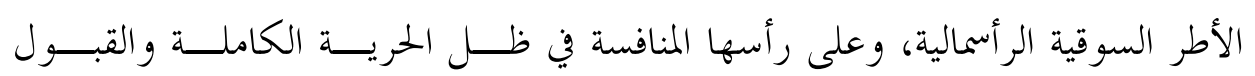

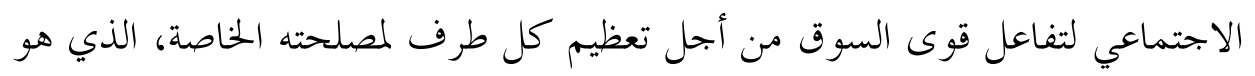

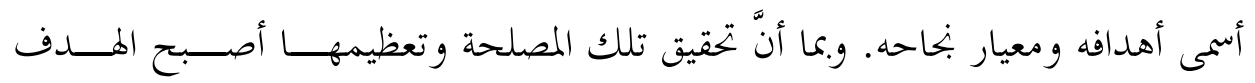

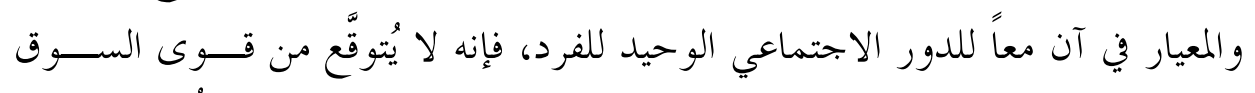

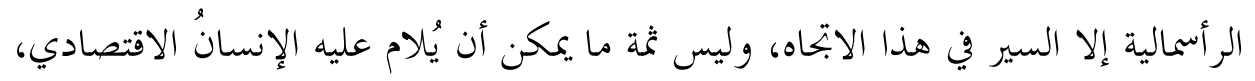

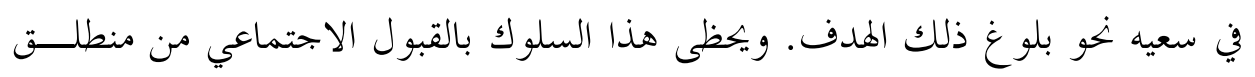

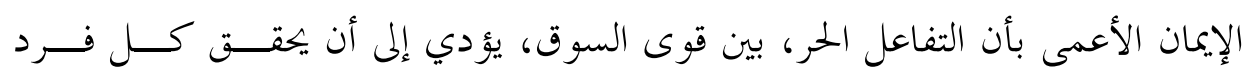

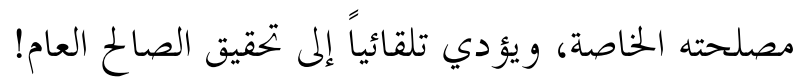

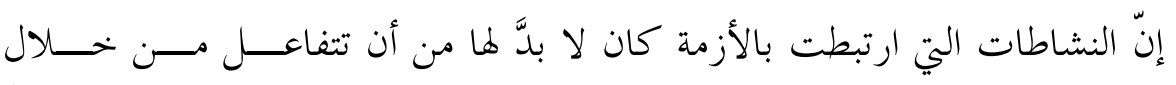

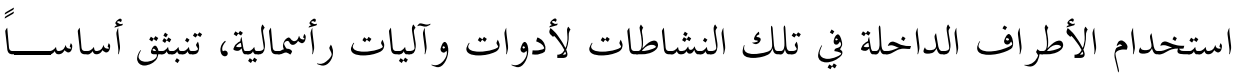

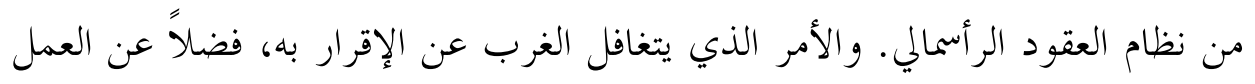

- Florescu (cas.Gherghel), Drd. Laura. Human Behavior, Economic Theories and Financial Crisis, The International Conference of Economics and Administration, Faculty of Administration and Business University of, Bucharest, Romania, 14-15th Nov., 2009. p. 304.

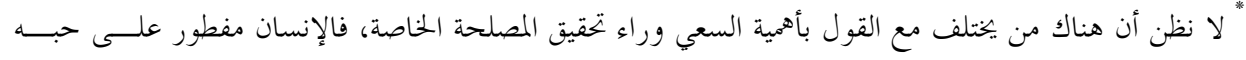

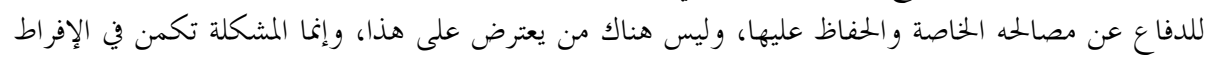

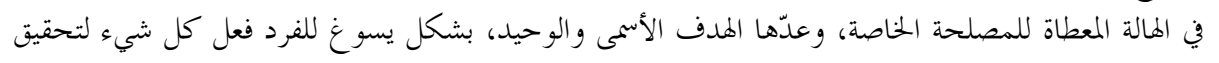

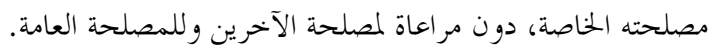




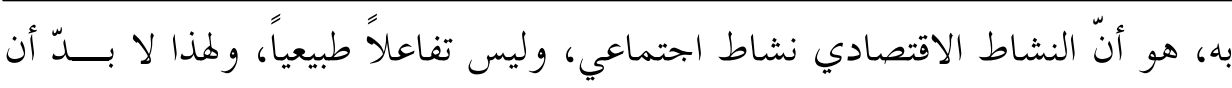

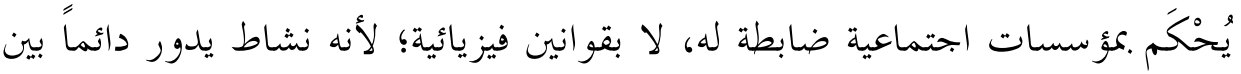

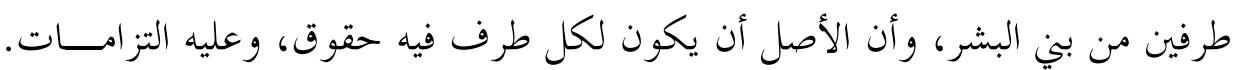

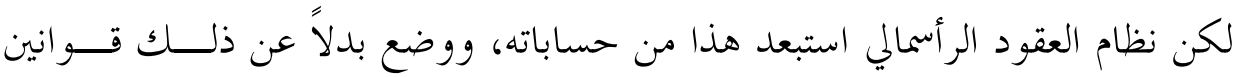

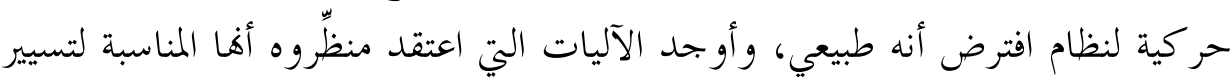

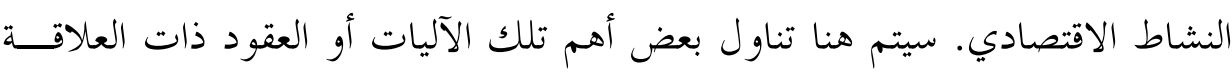

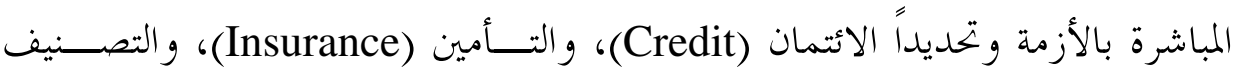
(Rating) بشفافية أدق، الفساد الأخلاقي.

لقد خضع استخدام الائتمان تاريخياً إلى قو اعد ناظمة له وضمانات؛ مثّلت أصولاً حقيقية، تكفل حقوق الأطراف الداخلة فيه، خاصة في حالة العجز عن الســـداد. وفي ظل هذه المعطيات، لا توجد مشكلة في استخدام الائتمان، وإنما تكمـــن المشــكلة في التوسع فيه، في ظل معطيات أخرى وظروف اقتصادية معينة، وفي التراخي في تطبيـق

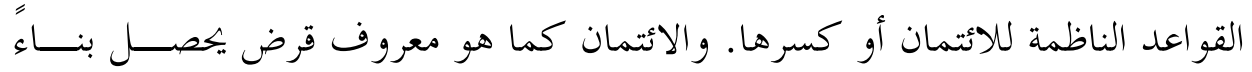
عليه المدين، أحد الطرفين، على مقدار من التمويل من الطرف الآخر: الدائن، بشروط متفق عليها ضمن قواعد و اضحة، متفق عليها وملزمة للطرفين، بما في ذلـــك البــــل

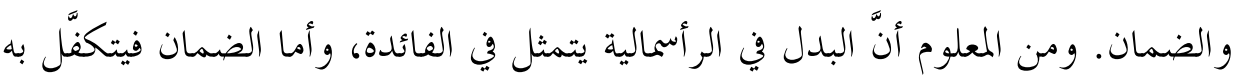
التأمين.

من ناحية أخرى، لقد كان الإقراض أو الائتمان يتم -سابقاً في الغرب- بالطريقة التقليدية المعروفة؛ بأن تقوم المؤسسات المعنية بالإقراض بإعطاء القروض والاحتفاظ هـا

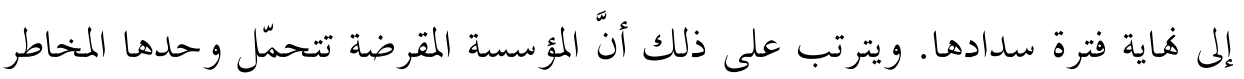
التي قد تنجم عن القرض في حال تعثر المدين. ولكي تحدّ المؤسسة المقرضة من حالات 
التعثر والوقوع في المخاطر، كانت حريصة على اختيار عملائها بحذر شديد، ولا تقبل منهم إلا من كانت لدية الملاءة الكافية.

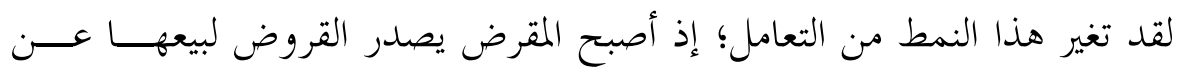

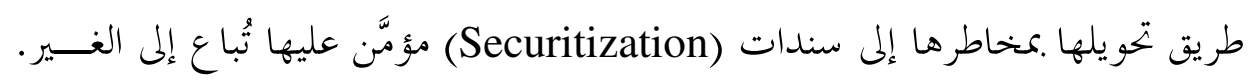

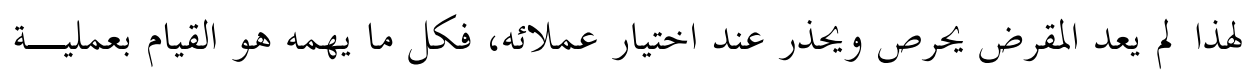

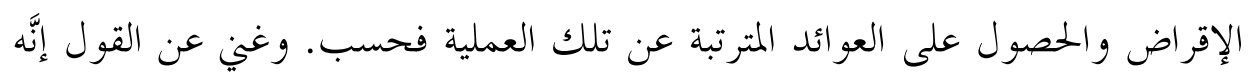

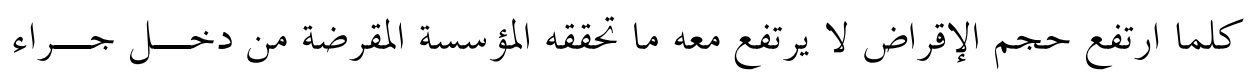

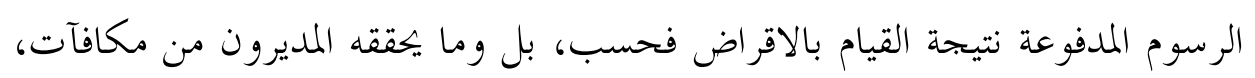

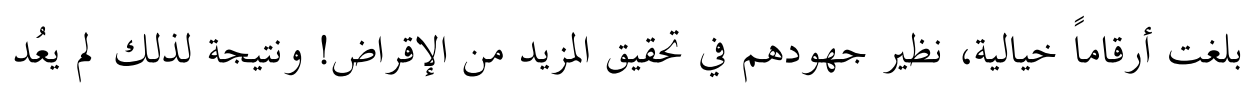

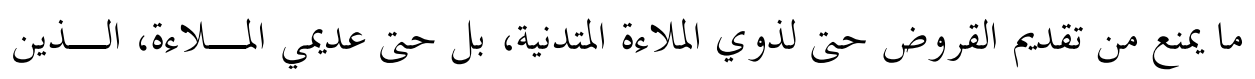

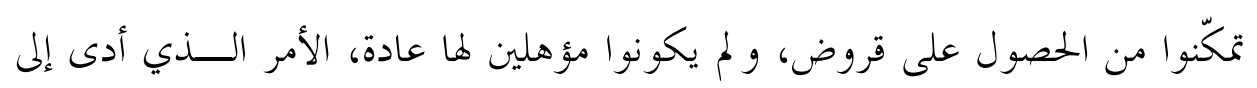

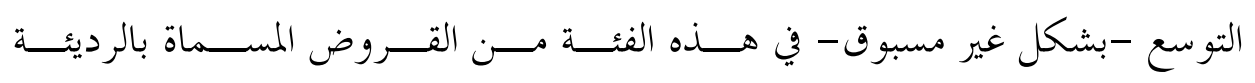
.(Subprime)

ونتيجة لاختلاف ملاءة المدينين، يسعى مولّدو القروض -بقصد بيعها والحصول

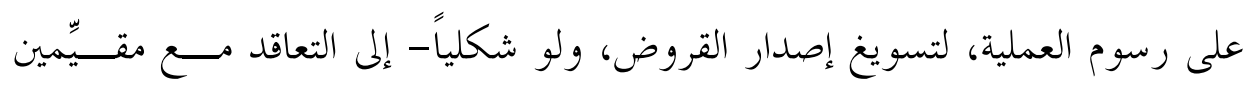

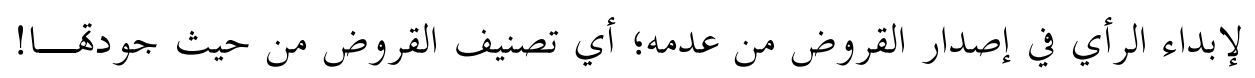

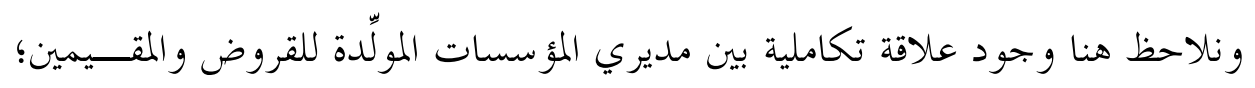

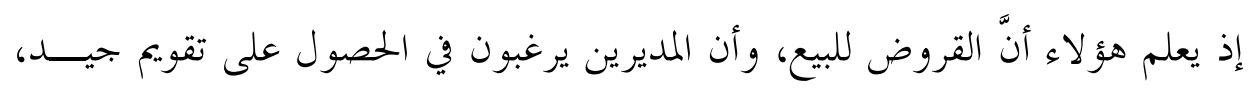

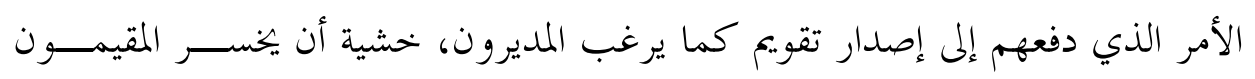

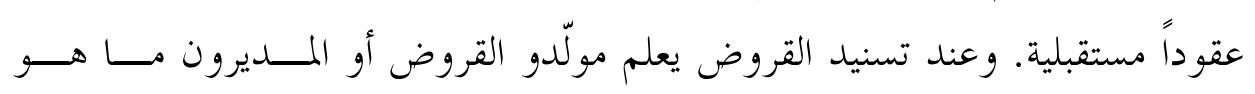

${ }^{24}$ Mitchell, Stephen and McGarry, John F. Recent Crisis: Roots and Lessons, in "Risk Management: The Current Financial crisis, Lessons learned and Future Implication", The Society of Actuaries. 2009, p.50. 
المطلوب لإعداد القروض، ورقياً، كي تستوفي هذه شروطاً سوقية بعينها، لتصبح قابلة

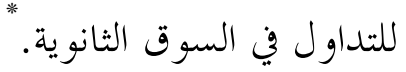

ومن ناحية أخرى، فمشترو القروض المسندة، وهي غالباً صــناديق الاســثتمار

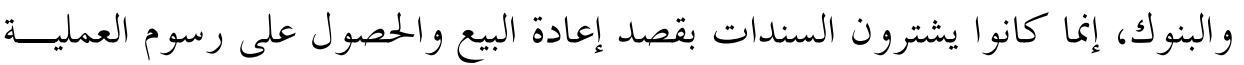

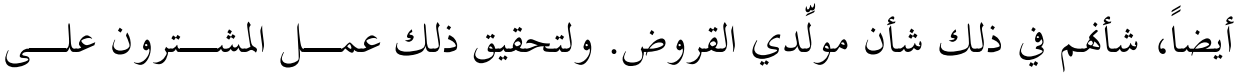

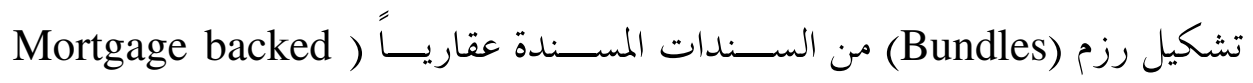

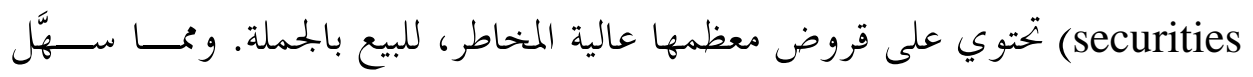

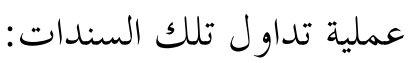

أ. انتشار استخدام أدوات مالية حديثة ومعقدة ابتـــعها "مهندســـــــالأدوات

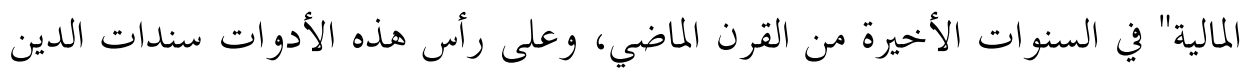
المضمونة (Collaterized Debt Obligation - CDOs).

ب.قدرة مولّدي سندات الدين المضمونة على الحصول على تصنيف اســتماري

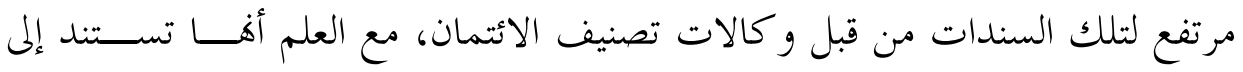
قروض عقارية عالية المخاطرة.

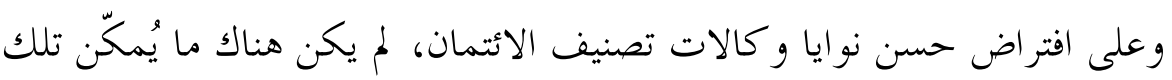

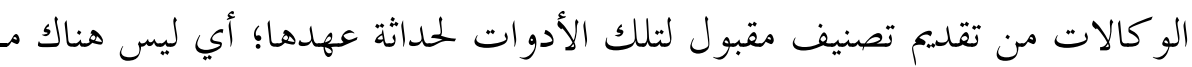

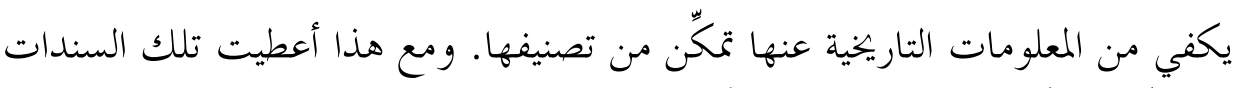

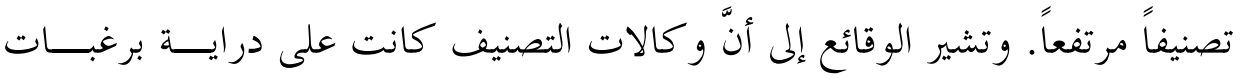

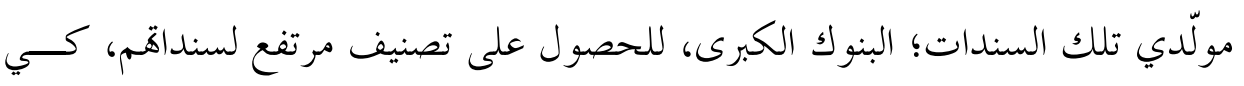

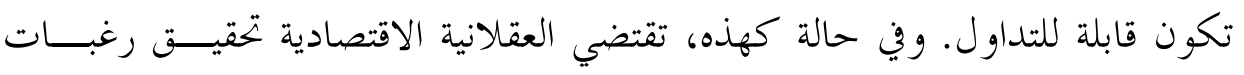

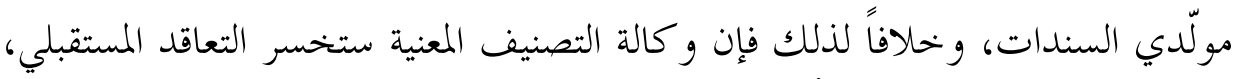

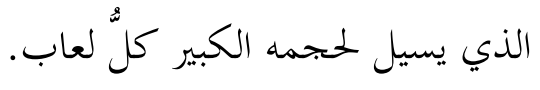

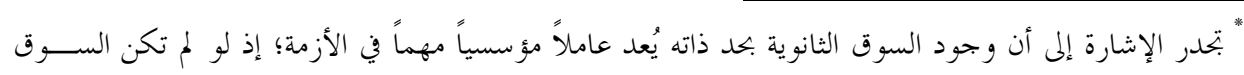

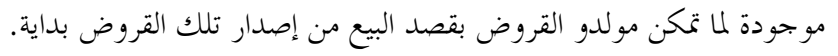




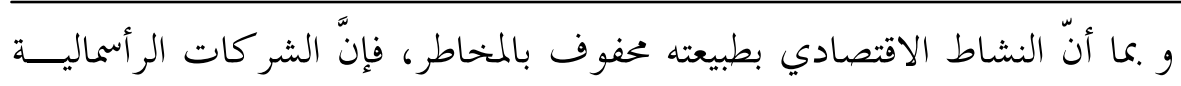

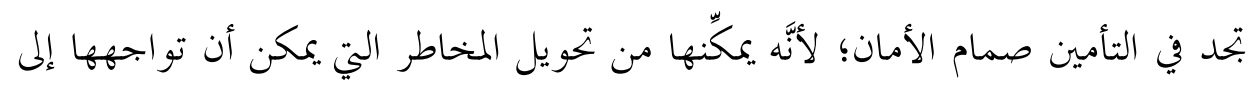

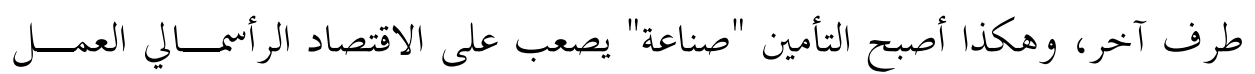

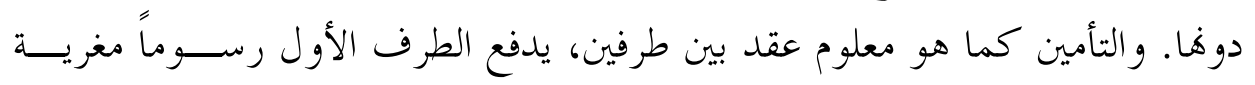

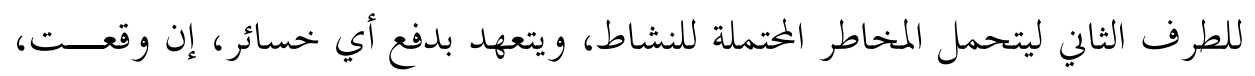

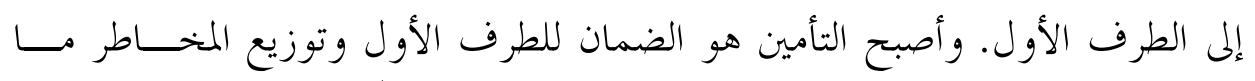

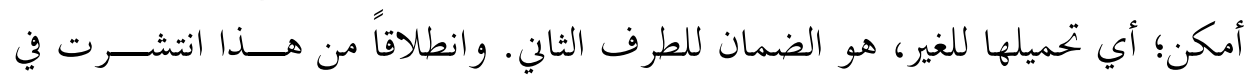

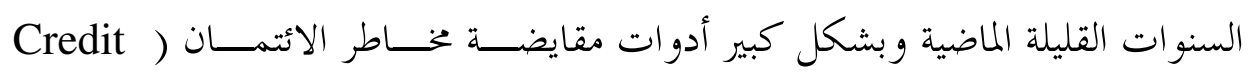
Default Swaps- CDSs

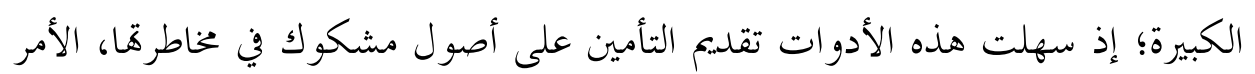

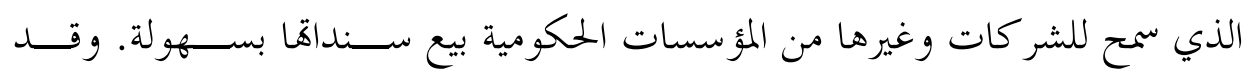

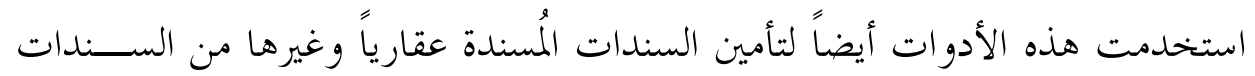

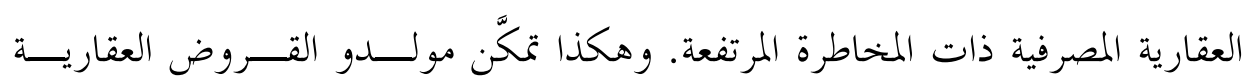

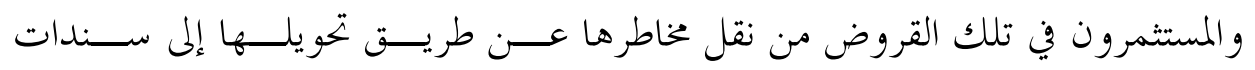

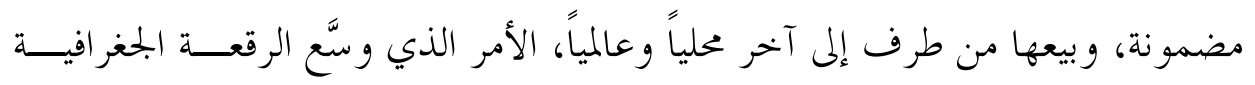
ro.

ومما زاد في حدة الأزمة أنَّ صناديق الاستثمار و التحوُّط قامت باستثمار أمـــوال

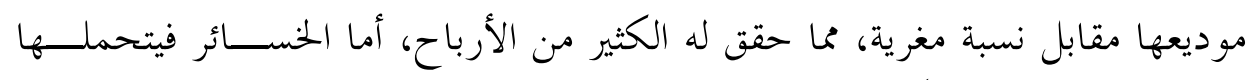

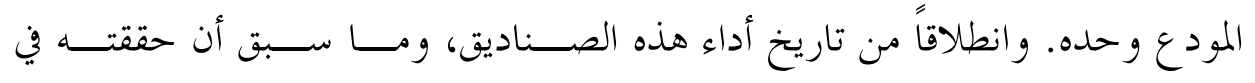

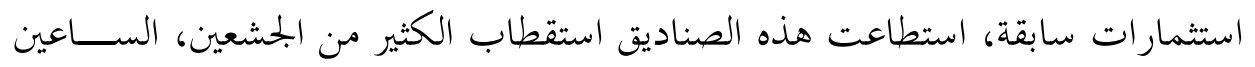

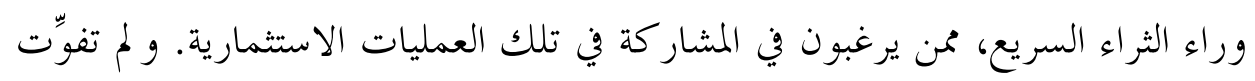
البنوك هذه الفرصة أيضاً؛ إذ أخذات تسير في طريق الصناديق. وسعياً وراء تحقيق المزيد

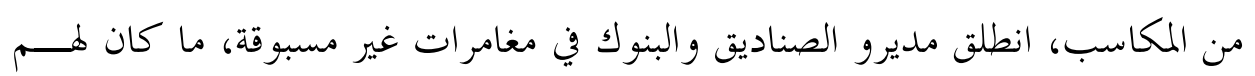

25 Baker, Dean. The Housing Bubble and the Financial Crisis, RealWorld Economics Review, issue no. 46, 2008, pp. 73-81. 
الدخول فيها لو كانوا يتعاملون بأموالهم الخاصة، مدفوعين بالمكافآت الخياليــة الــتي

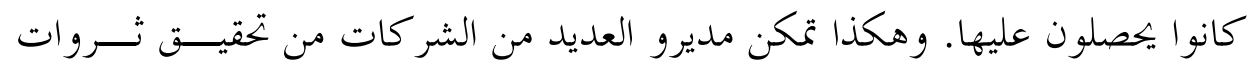
هائلة، ولكن على أنقاض شر كاتم.

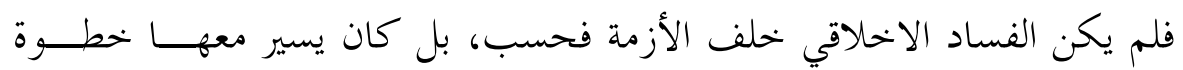

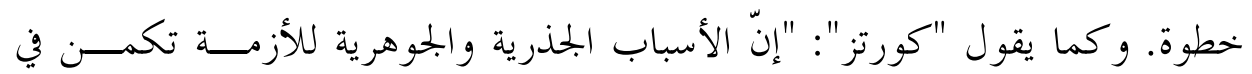

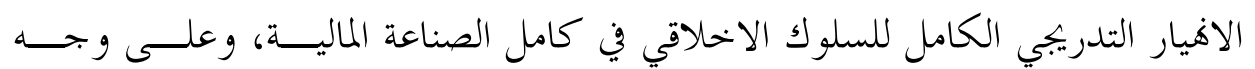

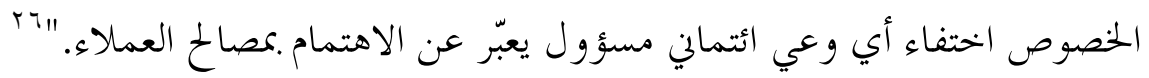

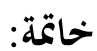

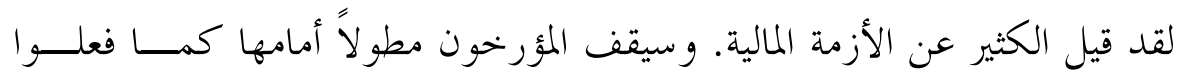

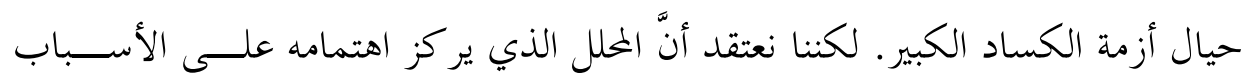

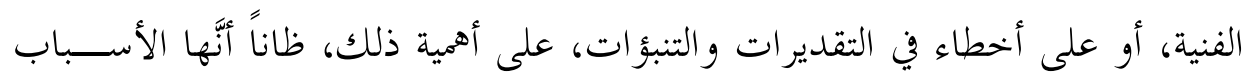
الكامنة وراء الأزمة، لن يصل إلى فهم مقبول للأزمة؛ لأنَّ هذا التناول للقضية تنــاول سطحي؛ إذ لا يمكن لأزمة هذا الحجم والاتساع و الآثار أن تكون وليدة هفوات فنية،

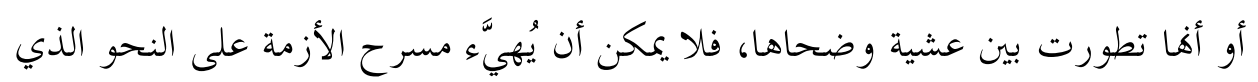

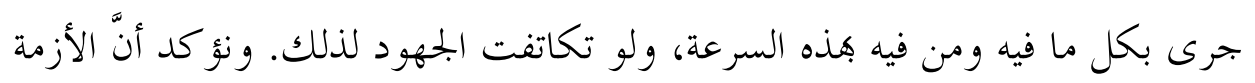
بكل أبعادها هي أزمة رأسمالية بامتياز، في عو امل انبعاثها، و وي إطارها المؤسسي. وما لا يختلف عليه المراقبون، هو أنَّ الاقتصاد الغربي بشكل عـــام، والأمريكــي

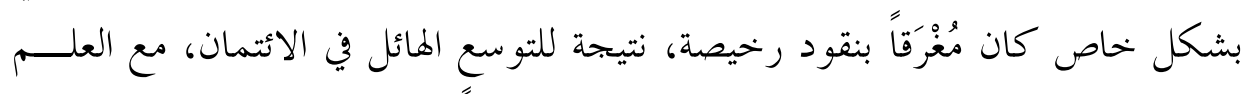

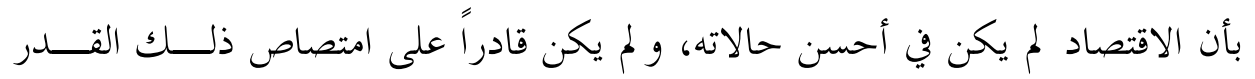

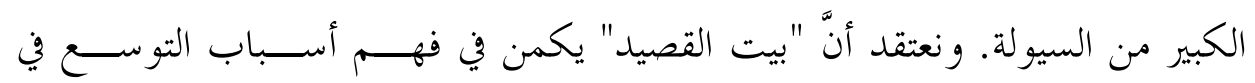

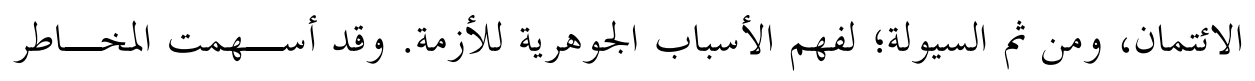

${ }^{26}$ Curtis, Gregory. The Financial Crisis and the Collapse of Ethical Behavior, White Paper no. 44, Greycourt \& Co., Inc. 2008, p. 1. 


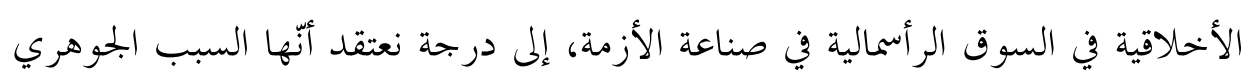

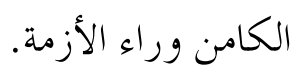

ومنذ أن بدأ التعامل بالنقود الورقية الرسمية، أصبح بالامكان التوسع بعرض النقود

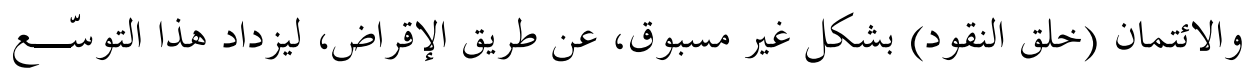

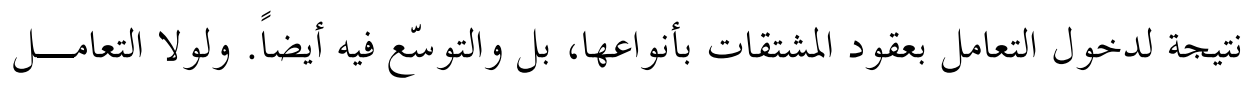

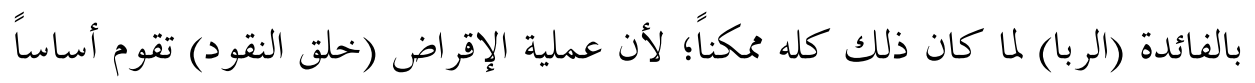

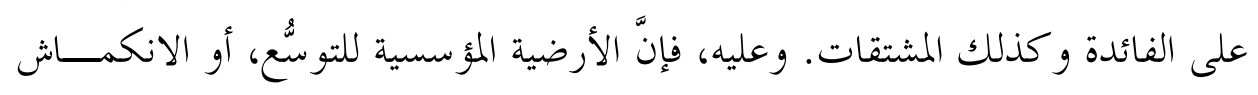

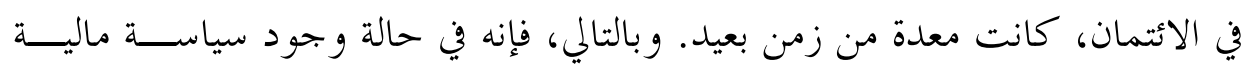

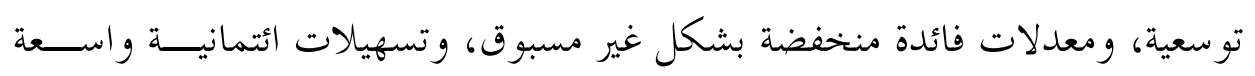

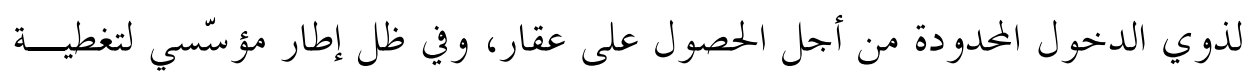

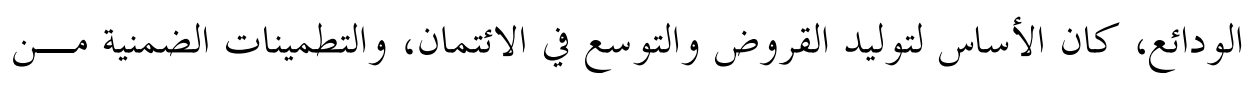

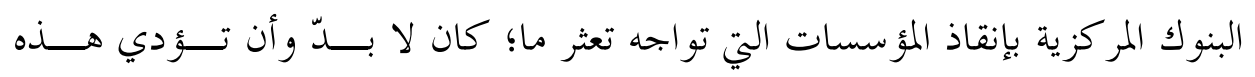

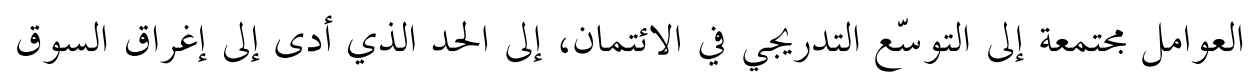

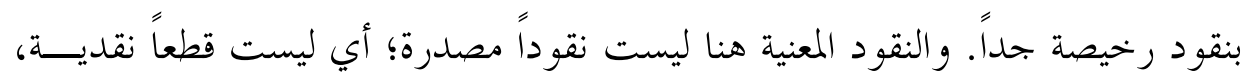

$$
\text { و وإنما هي نقود تم "خلقها" عن طريق الإقراض؛ أي إذا نقود دفتردية. }
$$

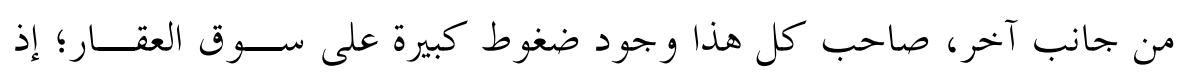

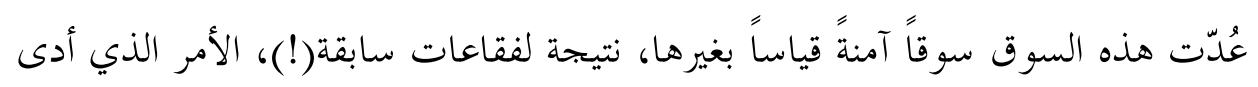

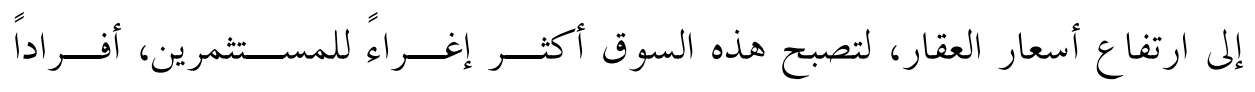

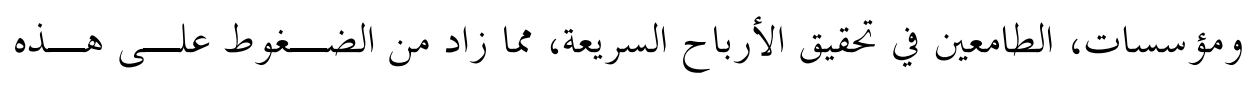
السوق. وهنا دخل الاقتصاد برمته في عملية مر اهنات.

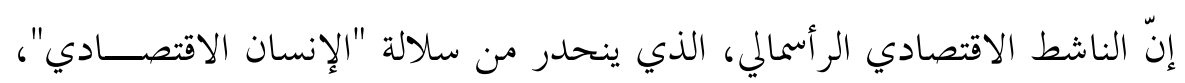

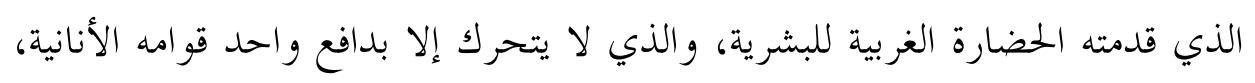

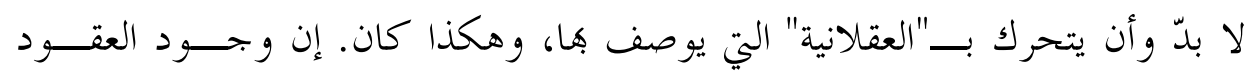




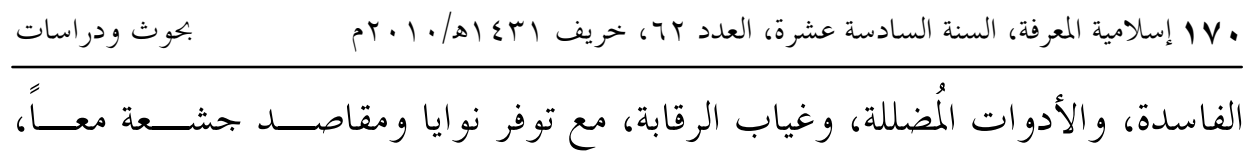
لتحقيق الأهداف الخاصة، والتحصن من المسؤولية عن القرارات الخطرة، والســماح

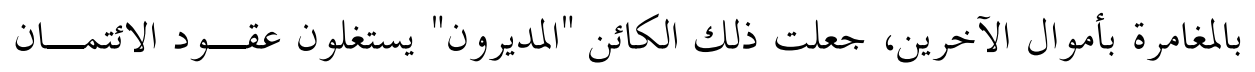

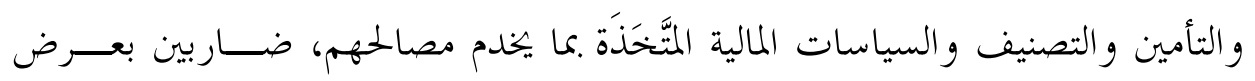
الحائط مصالح مالكي الشركات التي كان يديروفا و المواطنين، بل و الاقتصـــاد كلـــه، الأمر الذي ما كان ليقع لو كان المديرون يتعاملون بأموالهم الخاصة في ظل مؤسسات غير تلك التي تم التعامل من خلالها. وعلى هذا فإنّ الأسباب الجوهرية الكامنـــة وراء

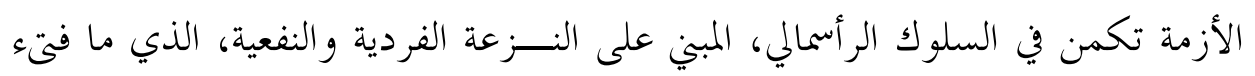

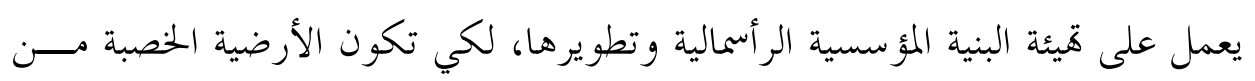
أجل تحقيق الفرد مصلحته الخاصة بكل الوسائل المتاحة. 